\title{
Evaluating polar pesticide pollution with a combined approach: a survey of agricultural practices and POCIS passive samplers in a Tunisian lagoon watershed
}

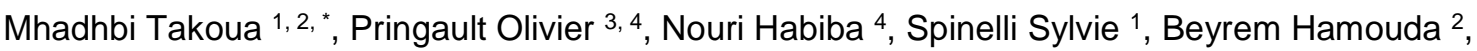 \\ Gonzalez Catherine ${ }^{1}$
}

1 Univ Montpellier, IMT Mines Ales, Lab Ind Environm Engn LGEI, Ales, France.

2 Univ Carthage, Fac Sci Bizerte, Lab Environm Biomonitoring LBE, Ave Republ, Tunis, Tunisia.

3 Univ Montpellier, IFREMER, CNRS, UMR 9190,MARBEC,IRD, Montpellier, France.

${ }^{4}$ Inst Rech Dev, Tunis, Tunisia.

*Corresponding author : Takoua Mhadhbi, email address : mhadhbitakoua@gmail.com

\begin{abstract}
:
A study of pesticides in the Bizerte lagoon watershed on the Mediterranean coast of Tunisia showed that herbicides and fungicides are the most commonly used compounds. A survey was made of selected farmers. Pesticide contamination was monitored in the water column and sediments at four selected sampling sites (lagoon (A) and in three ouedsChegui (B), Garaa (C), and Tinja (D)). Polar organic chemical integrative samplers (POCIS) were used to assess pesticide contamination. Thirty-two pesticides were investigated; the total concentration of active ingredients ranged from $35.9 \mathrm{ngL}(-1)$ in Tinja oued to $1246 \mathrm{ngL}(-1)$ in Chegui oued. In the lagoon, the total concentration of pesticides was $67.7 \mathrm{ngL}(-1)$. In the sediments, the highest concentration was measured in Chegui oued in the spring (31ngg(-1) dw). The main compounds found in the analyzed sediments were prosulfocarb and tebuconazole molecules.
\end{abstract}

Keywords : Agriculture, Tunisian lagoon, Pesticides, POCIS, Sediments 


\section{Introduction}

5 The impact of agricultural activities on the environments has strongly increased in the last

6 decade. The use of pesticides improves crop productivity by reducing the adverse effects of

7 pathogens (Ben Salem 2017), but their exces can be a major source of ecosystem pollution

8 (Arellano-Aguilar et al. 2017). Monitoring of the contamination of water and sediments by

9 pesticides is thus needed to evaluate the impact of human activities on ecosystems (ESF10 Marine Board 2011).

11 Pesticides can reach aquatic ecosystems via direct applications, spray drift, aerial spraying, 12 atmospheric fallout, soil erosion and runoff from agricultural land, discharge of industrial and 13 domestic sewage, leaching, careless disposal of empty containers and equipment washing 14 (Kaushik et al. 2010). Many of these compounds have been detected in different matrices, 15 including surface water (De Gerónimo et al. 2014; Palma et al. 2014), sediments (Guo et al. 16 2014; Li et al. 2014), fish pulp (Zhang et al. 2012; Yohannes et al. 2014) and bivalves 17 (Boonyatumanond et al. 2002; Khaled et al. 2004; Carro et al. 2014; Herceg-Romanić et al. 18 2014). Guidelines for concentrations of pesticides in waters are published by the International 19 Union of Pure and Applied Chemistry (IUPAC) (Hamilton et al. 2003) and permissible limits 20 are laid down in the European reports: 2008/105/EC (EU 2008) and 2013/39/EU (EU 2013).

21 In Tunisia, the use of pesticides has increased in recent years due to the expansion of 22 agricultural activities. Although national legislation on their uses is scarce, their 23 concentrations are regulated by the Stockholm convention (2004), with serious restrictions on 24 the use of several compounds, including aldrin, chlordane, dieldrin, endrin, heptachlor, 25 hexachlorobenzene (HCB), mirex and toxaphene molecules (Ben Salem et al. 2016). In 2016, 
1668 commercial pesticides were approved for use by Tunisian legislation (Mezghani et al.

2 2016); these products have to be homologated before being sold to ensure that they do not

3 pose a risk to human health and the environment. Pesticides comprise $31 \%$ insecticides, $39 \%$

4 fungicides, 20\% herbicides and 8\% other products (rodenticides, nematicides, etc.) (Mezghani 5 et al. 2016).

6 The Bizerte lagoon is one of the most important economic areas in Tunisia with farming, 7 fishing, ceramics, metallurgy, oil refineries and tire production (Barhoumi et al. 2014). 8 Agriculture represents a major activity in the zone with cereal crops accounting for 7,800 ha, 9 vegetables for 3,400 ha and tree crops for 500 ha (Barhoumi 2014). Large quantitites of 10 fertilizers and pesticides are used to increase productivity (Necibi et al. 2015), and as a 11 consequence, the quality of the lagoon water might be affected by the discharge of effluents 12 (Macdonald et al. 2005; Botta et al. 2009). This environmental pollution is not only a concern in Tunisia, but it has been the subject of studies worldwide in recent years (Comoretto and Chiron 2005; Vryzas et al. 2009; Momplaisir et al. 2010; Palma et al. 2014). The protection of coastal wetlands, including lagoons, in the Mediterranean region has become a priority in resource conservation policies. Like other countries around the world, Tunisia reacted to increasing anthropogenic pressures by developing several national regulations and participating in several internationnal Conventions; e.g., Ramsar Convention (FAO 2015) and Stockholm Convention (UNEP 2001). In previous studies on the Bizerte lagoon, Barhoumi et al. (2013) and Ben Salem et al. (2016) detected organochlorine pesticides (OCPs) in sediments with total concentrations of $11.5 \mathrm{ng} \mathrm{g}^{-1} \mathrm{dw}_{\text {and }} 574 \mathrm{ng} \mathrm{g}^{-1} \mathrm{dw}$, respectively. Several other authors also reported the presence of pollutants in the Bizerte lagoon, including inorganic mercury, methyl-mercury (Mzoughi et al. 2002), organotin (Mzoughi et al. 2005) and polycyclic aromatic hydrocarbons (Mzoughi et al. 2002; Barhoumi et al. 2016). Necibi et 
1 al (2015) found OCPs and polychlorinated-biphenyl (PCBs) in water samples collected from

2 the lagoon.

3 However, there is no published literature on the pollution of the lagoon ecosystem by polar

4 pesticides, mainly herbicides and fungicides. Water quality is usely monitored by spot (grab)

5 sampling, but due to the low concentrations of micro-pollutants (trace level), a large volume

6 has to be collected to enable detection of these molecules (Poulier et al. 2014). and this

7 sampling has to be repeated frequently to obtain a diagnosis of contamination over time

8 (Greenwood et al. 2007). Thanks to its ability to accumulate pollutants through time-weighted

9 average concentration (TWAC), in recent decades passive sampling has been widely used to

10 increase the representativeness of the contamination of different water bodies (surface water,

11 lakes, marine water, etc.) (Ahrens et al. 2015). Polar organic chemical integrative samplers 
1 depth is $7 \mathrm{~m}$ (Béjaoui et al. 2008). A $7 \mathrm{~km}$ long channel (300 m wide and $12 \mathrm{~m}$ deep) connects

2 the lagoon to the Mediterranean Sea. The lagoon is supplied with fresh water from the

3 surrounding $384 \mathrm{~km}^{2}$ watershed through seven oueds (M'razig, Garaa, Guenine, Ben Hassine,

4 Chegui, Gharek and Tinja) (Fig. 1). By definition, an oued is a stream whose size depends on

5 the quantity of rainfall. It can be a big river or a small stream (Ben Salem 2017). The

6 watershed receives waste from several anthropogenic activities (aquaculture waste, industrial

7 sewage, fertilizers and pesticides) (Ben Said et al. 2010). The Bizerte lagoon watershed is

8 surrounded by agricultural zones (Tinja, Menzel Bourguiba, and South of Bizerte) (Fig.1).

9 The smallest agricultural areas are located in the Tinja region, particularly around Tinja oued (D). The area represents $39 \%$ of the total area. The majority of crops planted there are cereals and fodder crops. One oued was selected in each of the three areas for sampling; Chegui oued (B) (Menzel Bourguiba), Garaa oued (C) (South of Bizerte) and Tinja oued (D) (Tinja) (Fig. 1). The Chegui oued (B) is located in the downstream part of the Bizerte lagoon watershed, with a high percentage of arable land. The two other oueds are situated in the upstream part of the catchment with a smaller percentage of arable land. These surrounding oueds discharge their effluents into the lagoon, and for this reason, a lagoon sampling site (A) was chosen to study the impact of agricultural pesticides on this aquatic ecosystem. To combat fungal diseases and weeds, farmers apply different pesticides depending on the season. Hence, samples were collected in three sampling campaigns in October 2015 (autumn), March 2016 (spring) and June 2016 (summer).

2.2 Survey of pesticides used: methodology

Three zones (South of Bizerte, Tinja and Menzel Bourguiba) were chosen to investigate the pesticides used. Data was first collected from the Regional Commissioner for Agricultural Development (RCAD) and their representatives in delegations called Extension Territorial Cells (ETC), to better understand the characteristics of the watershed. Representative samples 
1 of the general population of farmers were interviewed (50 people), all of whom cultivate land

2 around the Bizerte lagoon (Fig.1). The farmers who were selected for the survey were those

3 whose land was located closest to the lagoon and to the oueds that feed the watershed. The

4 interview was semi-directive.

5 The interviews were structured in two parts: the first part collected general information (age,

6 gender, level of education), while the second part focused on farming (extent of arable land, 7 type of crops cultivated, disease frequency, pesticides used, period and frequency of

8 treatments). The field survey was carried out in February and March 2015.

9 A list of commercial pesticides with numerous active ingredients was drawn up based on the 10 data and on the information collected in the survey. For each commercial pesticide, the 11 suppliers provided the dose per gram and per hectare, and the dose of active ingredients per 12 hectare was determined according to the pesticide formula. The concentration of active 13 ingredients used by farmers was calculated based on the dilution and the volume of water sprayed per hectare (applied dose $\mathrm{g} \mathrm{ha}^{-1}$ ). A list of active ingredients was selected and ranked according to this dose $\left(\mathrm{g} \mathrm{ha}^{-1}\right)$.

\subsection{Water sampling procedures}

Both passive and grab sampling was performed at the four sites (the lagoon ((A); $37^{\circ} 10.957^{\prime} \mathrm{N}$

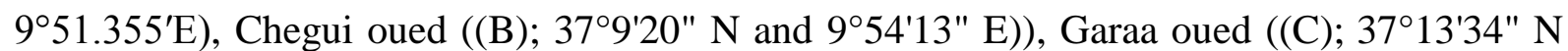
and 9 44'29" E) and Tinja oued ((D); 37 11'18" N and 946'54"E) (Fig. 1). Three sampling campaigns were conducted in October 2015 (autumn), March 2016 (spring) and June 2016 (summer). At each site, POCIS were deployed in triplicate $(n=3)$ for a mean period of 21 days (Ibrahim et al. 2013b). They were placed in cages and submerged vertically in the water column. As quality control, a field blank was transported to the site and exposed to the air each time the immersed samplers were retrieved from the water (Ibrahim et al. 2013b). On the days of the deployment and retrieval of the POCIS samplers, grab water samples were 
1 collected in clean amber glass bottles at the spot where each cage was immersed. The

2 retrieved POCIS were rinsed with ultrapure water, wrapped in aluminum foil and placed in a

3 plastic bag. Both grab and POCIS samples were stored in cool conditions during transport to

4 the laboratory and until extraction. During each sampling campaign, the physical parameters

5 (water column temperature, $\mathrm{pH}$, dissolved oxygen, and salinity) were determined using field

6 multi-parameter sensors.

$7 \quad 2.4$ Sediment sampling procedure

8 Sediment samples were collected at the four selected sites in the Bizerte lagoon watershed

9 (the lagoon (A), Chegui oued (B), Garaa oued (C) and Tinja oued (D)) (Fig. 1), at three sampling campaigns (autumn, spring, summer). Sediments were sampled using plexiglass cylindrical cores $(30 \mathrm{~cm}$ long, $3.6 \mathrm{~cm}$ diameter). Only the superficial sediment layer (less than $10 \mathrm{~cm}$ ) was sampled. Three replicates were collected per sampling site then transferred to an icebox in the dark. In the laboratory, the samples were kept in the freezer until extraction.

Before extraction, frozen samples were freeze-dried then passed through a stainless steel sieve (200- $\mu \mathrm{m}$ mesh) and stored at $4{ }^{\circ} \mathrm{C}$ until analysis (Barhoumi et al. 2013).

2.5 Analytical procedures

\subsubsection{Chemicals and materials}

Thirty-two targeted compounds, mainly herbicides and fungicides, were analyzed (Table1). The compounds included 25 pesticides (Acetochlor, Alachlor, Atrazine, Azoxystrobin, Carbendazim, Chlortoluron, Dimethomorph, Diuron, Epoxiconazole, Flazasulfuron, Imidachloprid, Isoproturon, Linuron, Metalaxyl, Metholachlor, Oxadixyl, Penconazole, Prochloraz, Propyzamide, Prosulfocarb, Pyrimethanil, Simazine, Tebuconazole, Terbuthylazine, Tetraconazole) and seven degradation products (DCPMU, DCPU, DEA, DET, DIA, Simazine hydroxy, Terbuthylazine hydroxy). 
1 Analytical standards (purity > 99\%) were purchased from Cluzeau Info Labo (Sainte Foy la

2 Grande, France). Deuterated-labeled compounds were atrazine-d5 (CAS: 163165-75-1) as

3 recovery control and simazine-d5 (CAS: 220621-41-0) as internal standard. High

4 performance liquid chromatography (HPLC) grade solvents used were acetonitrile from

5 Biosolve (Dieuze, France) and formic acid from Carlo Erba Reagents (Peypin, France).

6 Ultrapure water was generated with a MilliPore Synergy UV water purification system from

7 Merck Millipore (Billerica, US). Glass-fiber filters $(\mathrm{GF} / \mathrm{F})(0.7 \mu \mathrm{m}$ pore size) purchased from

8 Whatman (Maidstone, UK) were used to filter the water samples. Oasis HLB ${ }^{\circledR}$ cartridges (60

$9 \mu \mathrm{m}, 6 \mathrm{~cm}^{3}, 500 \mathrm{mg}$ ) were obtained from Waters Corporation (Milford, USA) and a Visiprep 10 Solid Phase Extraction (SPE) vacuum manifold from Supelco (Bellefonte, USA) was used for 11 SPE. POCIS were purchased from Expos Meter AB Company (Tavelsjö, Sweden) with the 12 pharmaceutical receiving phase comprised of approximately $230 \mathrm{mg}$ of the solid adsorbent $\mathrm{N}$ 13 vinylpyrrolidone-divinylbenzene (Oasis HLB ${ }^{\circledR}$ ). The sampling area of the POCIS device was $41 \mathrm{~cm}^{2}$. The $3 \mathrm{~mL}$ polypropylene cartridges used to recover the POCIS receiving phases were from Supelco (Bellefonte, USA).

\subsubsection{POCIS and water sample extraction}

Grab samples $(500 \mathrm{~mL})$ were filtered through $\mathrm{GF} / \mathrm{F}$ filters to eliminate suspended matter, spiked with $50 \mu \mathrm{L}$ of atrazine d5 (1 ng $\mu \mathrm{L}^{-1}$ acetone) and extracted by solid phase extraction (SPE) using Oasis $\mathrm{HLB}^{\circledR}$ cartridges. Prior to extraction, the Oasis $\mathrm{HLB}^{\circledR}$ cartridges were activated with $5 \mathrm{~mL}$ of acetonitrile under vacuum, followed by $5 \mathrm{~mL}$ of methanol $(\mathrm{MeOH})$ and $5 \mathrm{~mL}$ of ultrapure water (Ibrahim et al. 2013b). Before elution, they were dried under vacuum for 1 hour. Analytes were recovered by eluting the cartridges with $8 \mathrm{~mL}$ of

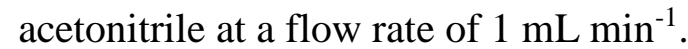

After they were retrieved, the receiving phases of the POCIS were transferred into an empty solid-phase extraction tube packed with polyethylene (SPE) frit, $20 \mu \mathrm{m}$ porosity. The sorbents 
1 were spiked with $50 \mu \mathrm{L}$ of atrazine d5 (1 ng $\mu \mathrm{L}^{-1}$ acetone) then eluted with $8 \mathrm{~mL}$ of

2 acetonitrile.

3 Both for Oasis $\mathrm{HLB}^{\circledR}$ cartridges and POCIS receiving phase elution, the extracts were

4 concentrated under a gentle stream of nitrogen to obtain a final extract of $1.5 \mathrm{~mL}$. This final

5 extract were then spiked with $150 \mu \mathrm{L}$ of the internal standard simazine d5 $\left(1 \mathrm{ng} \mu \mathrm{L}^{-1}\right.$

6 acetonitrile) and analyzed by HPLC-MS/MS (Ibrahim et al. 2013).

$7 \quad$ 2.5.3 Sediment extraction

8 The extraction was carried out using an Accelerated Solvent Extraction (ASE) system

9 (Dionex ${ }^{\circledR}$, France) with a hexane/acetone mixture of solvents $(50 / 50$, v/v). The parameters used during the extraction procedure were as follows: temperature $120^{\circ} \mathrm{C}$, static time 5 min, pressure $1500 \mathrm{psi}$, heating time $6 \mathrm{~min}$, flush volume 60\%, and purge time $100 \mathrm{~s}$. Atrazine d5 recovery control ( $1 \mathrm{ng} \mu \mathrm{L}^{-1}$ acetonitrile) was added to the sediment prior to the ASE step and the resulting extracts (hexane/acetone) were cleaned on a Strata SAX ${ }^{\circledR}$ (8B-S008-JCH). To recover analytes, elution was carried out with $3 \mathrm{~mL}$ of $\mathrm{MeOH}$ and $3 \mathrm{~mL}$ of dichloromethane $\left(\mathrm{CH}_{2} \mathrm{Cl}_{2}\right)$, respectively. Purified extracts were completely evaporated under a gentle stream of nitrogen and then dissolved in $1.5 \mathrm{~mL}$ of acetonitrile (Barhoumi et al. 2013). Before analysis, all sample extracts were spiked with $120 \mu \mathrm{L}$ of the deuterated internal standard simazine d5 (1 ng $\mu \mathrm{L}^{-1}$ acetonitrile) and then analyzed by HPLC-MS/MS.

The percentage of finer grain size fractions $(<63 \mu \mathrm{m})$ of each sediment sample was determined gravimetrically after wet sieving (Savinov 2000). Total organic carbon (TOC) content was measured using the coulometry method in a 702 Coulomat, after decarbonization of sediments with $2 \mathrm{~N} \mathrm{HCl}$ at $60{ }^{\circ} \mathrm{C}$ overnight (Ouertani et al. 2006).

2.5.4 Liquid chromatography-mass spectrometry (HPLC-MS/MS) analysis

The pesticide analysis was performed by HPLC-MS/MS using an Alliance HPLC system (Waters Series 2695). The HPLC is equipped with a quaternary pump, a vacuum degasser and 
1 an autosampler. Analytic separation was achieved with a Kinetex C18 analytical column (100

$2 \mathrm{~mm} * 4.6 \mathrm{I} . \mathrm{D} * 260 \AA$ A, Phenomenex). The volume injected was $25 \mu \mathrm{L}$. Acetonitrile (A) and

3 ultrapure water (B), both with $0.05 \%$ formic acid, were used as mobile phases at a constant

4 flow rate of $0.4 \mathrm{~mL} \mathrm{~min}^{-1}$. The linear gradient was started at $40 \%$ for $0.2 \mathrm{~min}$, ramped to $80 \%$

5 for $8 \mathrm{~min}$, then to $100 \%$ for $1 \mathrm{~min}$ and finally back to the initial conditions for $2 \mathrm{~min}$. A triple

6 quadrupole mass spectrometer (Micromass Quatromicro TM, Waters) equipped with an

7 electrospray ionization source (ESI) was used as the detector device. The spectrometer

8 operated in positive ESI mode under the following conditions: capillary voltage $(3.5 \mathrm{kV})$,

9 source temperature $\left(120{ }^{\circ} \mathrm{C}\right)$, desolvation temperature $\left(300{ }^{\circ} \mathrm{C}\right)$, drying $\left(600 \mathrm{~L} \mathrm{~h}^{-1}\right)$, and 10 nebulization gas $\left(\mathrm{N}_{2}\right)$ flow $\left(30 \mathrm{~L} \mathrm{~h}^{-1}\right)$. Argon was used as the collision gas. For each 11 compound, acquisition was performed in the multiple reaction-monitoring modes (MRM). 12 Two transitions were retained: one was used for quantification and the other for confirmation 13 (Table S1: Supplementary materials).

14 2.5.5 Concentrations of pesticides in the water during POCIS deployment

15 The accumulation of contaminants by passive samplers typically follows first-order kinetics, 16 which includes an initial integrative phase, followed by curvilinear and equilibrium17 partitioning phases. In the linear region of the POCIS uptake, the amount of a chemical 18 accumulated in the sampler $(M)$ is described by equation (1):

$$
M=C_{w} \cdot R_{s} \cdot t
$$

where $R_{s}$ is the sampling rate $\left(\mathrm{L} \mathrm{day}{ }^{-1}\right), C_{w}$ is the time-weighted concentration of the compound in water $\left(\mathrm{ng} \mathrm{L}^{-1}\right)$ and $t$ the exposure time (days).

For each pesticide, the sampling rate was determined by dividing the slope of the linear regression curve by the mean aqueous concentration of the selected compounds over the 15 days of exposure time (Ibrahim et al. 2013b). POCIS sampling rates (Table 1) were 
1 determined in laboratory conditions for each compound (Ibrahim et al. 2013b). Given that

2 they depend on environmental conditions such as flow, temperature, $\mathrm{pH}$, organic matter and

3 biofouling (Charlestra et al. 2012; Yabuki et al. 2016), they allow the calculation of semi-

4 quantitative concentrations of pesticides in water and the comparison of the relative levels of

5 contamination between sites (Ibrahim et al. 2013b). Time-weighted averaged concentrations

6 (TWAC) in water were calculated with the equation proposed by Miège et al. 2013 (2):

$$
C_{\text {water }}=C_{\text {pocis. }} M_{\text {pocis }} / \operatorname{Rs.} t(2)
$$

7 where $C_{\text {water }}$ is the mean concentration of the contaminant (over the sampling period) in the

8 ambient water $\left(\mu \mathrm{g} \mathrm{L}^{-1}\right) ; C_{\text {pocis }}$ is the concentration in the POCIS $\left(\mu \mathrm{g} \mathrm{g}^{-1}\right) ; M_{\text {pocis }}$ is the mass of 9 adsorbent phase in the POCIS (g); $R s$ is the sampling rate $\left(\mathrm{L} \mathrm{day}^{-1}\right)$, which corresponds to the volume of water purified per unit of time; and $t$ is the total exposure time (days).

Among the 40 compounds inventoried in the survey, 15 were selected (Table 2) as being the most representative, according to (i) the use rate per hectare; (ii) the type of crops grown in the zone; (iii) the concentration of active ingredient in the commercial pesticide. For analytical reasons, not all the selected active ingredients could be analyzed by the HPLCMS/MS method developed in our laboratory. In particular, glyphosate and 2,4 D were not included in the final list of targeted pesticides. The final list of active ingredients comprised 32 compounds analyzed by liquid chromatography mass spectrometry (Table 1).

\subsubsection{Quality assurance/control}

The linearity, limits of detection (LODs) and limits of quantification (LOQs), precision and accuracy of the analytical methods were carefully checked. The LODs were calculated as $3 \mathrm{Sy} / \mathrm{x} / \mathrm{b}$ and the LOQs as $10 \mathrm{Sy} / \mathrm{x} / \mathrm{b}$, where Sy/x is the residual standard deviation and $\mathrm{b}$ is the slope of the matrix calibration curves. The LODs and LOQs obtained by HPLC-MS/MS (analytical LOD and LOQ expressed in $\mu \mathrm{g} \mathrm{L}^{-1}$ ) are listed in Table 1. The LODs and LOQs of 
1 all the selected pesticides were detemined from the calibration curves for each analytical

2 campaign in which $\mathrm{R}^{2}>0.98$. The analytical limits of detection ranged from $0.10 \mu \mathrm{g} \mathrm{L}^{-1}$ to

$32.20 \mu \mathrm{g} \mathrm{L}^{-1}$ and the limits of quantification from $0.40 \mu \mathrm{g} \mathrm{L}^{-1}$ to $7.50 \mu \mathrm{g} \mathrm{L}^{-1}$. The LOQs of the

4 POCIS (which were calculated from the equation of (Poulier et al. 2014)), water and

5 sediment samples are also listed in Table 1.

6 Mean recovery from the synthetic water solution spiked with the 32 compounds was $63 \%$, the

7 highest recovery being for simazine (101\%) and the lowest for DCPU (8\%). Flazasulfuron,

8 hydroxy-terbuthylazine and hydroxy-simazine were not recovered (Table 1).

9 A certificated reference material (WaRTM Pollution Nitrogen Pesticides, Lot No, P246-674)

10 purchased from the ERA Waters Company (Golden, USA) was used to determine pesticide 11 recoveries in water samples. The reference material was a water solution composed of 24 12 pesticides including six of the pesticides selected for our study (Alachlor, Atrazine, DEA, DIA, Metolachlor and Simazine). The concentrations of pesticide in the reference material ranged between $16.80 \mu \mathrm{g} \mathrm{L}^{-1}$ and $3.37 \mu \mathrm{g} \mathrm{L}^{-1}$. The global recovery yields were for atrazine (108 $\pm 4 \%)$, for alachlor $(78 \pm 4 \%)$, for DEA $(61 \pm 3 \%)$, for DIA $(58 \pm 3 \%)$, for metolachlor (110 $\pm 2 \%)$, for simazine $(79 \pm 2 \%)$ after solid phase extraction (Oasis HLB) and HPLC-MS/MS analysis $(\mathrm{n}=9)$ with our laboratory method. The mean extraction recoveries with atrazine-d5 were $98 \pm 11 \%$ and $92 \pm 12 \%$ for the passive and grab samples, respectively ( $\mathrm{n}=36$ samples). The relative standard deviation (RSD) obtained for the analysis of the internal standard simazine-d5 was $17 \pm 6 \%$ for all the HPLC-MS/MS injections ( $\mathrm{n}=108$ injections).

\subsection{Statistical analyses}

Triplicate analytical measurements were made for all the analyses and the data are reported as mean \pm standard deviation. Pearson's correlation coefficient was calculated to investigate possible relationships between parameters. Statistical significance was set as $p<0.05$. The 
1 statistical treatment of the data was performed using the STATISTICA 6.0 Analysis System

2 version 5.

\section{3. Results and discussion}

\section{$4 \quad 3.1$ Survey results}

5 According to the farmers and engineers of Regional Commissioner for Agricultural

6 Development (RCAD), field crops (wheat, legumes and oats) occupy the largest percentage of 7 cultivated fields. Wheat accounts for $58 \%$ (i.e., 3.153 ha) of the total cultivable area, and 8 legumes and oats for $13 \%$ and $10 \%$, respectively. The dominance of this type of crop could be 9 related to economic factors. Indeed, since the 1970s, Tunisia and other North African countries have benefited from the support of ICARDA (International Center for Agricultural Research in Arid Zones) to develop their cultivar production programs, with the objective of intensifying the amount of cereal crops and legumes (Nefzaoui et al. 2012). This result is consistent with those obtained in an investigation commissioned by the Tunisian Ministry of Agriculture (DGEDA, 2006), which reported that the areas treated in Tunisia correspond to low crops, which represent $73 \%$ of all cereals grown.

Our survey results showed that farmers use 47 commercial pesticides, mainly fungicides (42.5\%), herbicides $(42.5 \%)$, and insecticides (15.0\%). The prospected regions are wetlands, where fungal diseases (Septoria, rust and mildew) develop easily, hence, intensive use of fungicides by farmers was observed. Fungicides are used twice a year (at the end of March and May) as preventive treatments. They are also used as a curative treatment for "rust" whenever there is an outbreak of the disease. The survey also revealed high use of herbicides to control the weeds that compete with crops for access to water, light and soil nutrients. Herbicides are usually applied twice a year, in autumn (October) and spring (March).

Table 2 lists the most frequently used active ingredients based on our inventory of commercial pesticides in the regions around the Bizerte lagoon surveyed. The active 
1 ingredients are classified first according to the type of pesticide (herbicides, fungicides and

2 insectides) then by the dose of the active ingredients applied per hectare (calculated according

3 to the dilution and the water volume sprayed per hectare) and by target crop, mainly field

4 crops (wheat, legumes, oats). The list contains 40 active ingredients (Table 2). Among these

5 compounds, 87.5\% are approved for use in Tunisia (Mezghani et al. 2016). Our list of active

6 ingredients is in agreement with the results of a study by Ben Salem et al. (2016), who used

7 another approach to calculate the total quantities of active ingredients, i.e., the percentage use

8 of active ingredients was calculated by dividing the number of farmers who used the active

9 ingredient concerned by the total number of farmers surveyed $(* 100)$. Finally, the amount of each active ingredient (Qsubstance) is the product of the cultivated area (ha) divided by the percentage of pesticide used by the assay of the active ingredient in the pesticide. Despite the different methods of calculation used in the two studies, some of the ingredients we found were also found by Ben Salem et al. (2016) including herbicides (e.g, Iodosulfuron, Mesosulfuron, 2,4-dichlorophenoxyacetic acid (2,4 D), Glyphosate, and Fenoxaprops) and fungicides (e.g, Tebuconazole, Epoxiconazole, Azoxystrobin). The study by Ben Salem et al. (2016) revealed that insecticides are the least used, and only two pyrethroids were inventoried (Deltamethrin and Bifenthrin).

For our study, based on the calculations of the dispersed dose $\left(\mathrm{g} \mathrm{ha}^{-1}\right)$, the inventoried active ingredients were ranked to obtain a list of 40 targeted compounds (Table 2). The survey revealed that most of the pesticides were used on wheat, legumes and oats, which are the main crops grown in the regions surveyed. A restricted list is thus proposed containing 15 active ingredients of fungicides (Azoxytrobin, Chlorothalonil, Prochloraz, Tebuconazole, Fluzilazole, Flutriafol, Propiconazole, Carbendazim, Prothioconazole, and Epoxiconazole) and herbicides (Glyphosate, Simazine, Bentazone, Prosulfocarb, 2,4D). The estimated concentrations of these compounds ranged from $200 \mathrm{~g} \mathrm{ha}^{-1}$ for Azoxystrobin to $0.47 \mathrm{~g} \mathrm{~h}^{-1}$ for 
1 Epoxiconazole. Despite their high dose per hectar, some pesticides were not included in this

2 list because they are not used to treat the field crops grown in the survey area, mainly wheat.

3 This is the case of Difenoconazole, Mancozeb, Maneb, Zineb, and Boscalid, which are used

4 to protect vines.

$5 \quad 3.2$ Surface water quality

$6 \quad 3.2 .1$ Occurence of pesticide in water

7 To study the occurrence of target pesticides, detection and quantification frequencies were

8 calculated, based on the results obtained by the two sampling techniques (grab and passive

9 sampler). By definition, the frequency of detection and quantification campaigns correspond 10 to the ratio of the number of times in which one compound was detected and quantified 11 divided by the total number of sites analyzed in the campaigns, respectively.

12 Of the 32 pesticides studied (Table 1), 23 were detected using passive sampling technique (Fig. 2A), which represents $72 \%$ of the total studied pesticides. Whereas, 11 compounds were quantified (34\%) with the same sampling technique (POCIS): Simazine, Chlortoluron, DIA, Acetochlor, Alachlor, DCPU, Isoproturon, DET, Epoxiconazole, Tebuconazole, Azoxystrobine (Fig. 2A). Among the detected compounds using POCIS, two fungicides (Epoxiconazole and Tebuconazole) and one herbicide (Simazine) were detected at a frequency of $100 \%$. The accumulation of these compounds in the POCIS receiving phase (OASIS HLB) is favored by their $\log K_{o w}$ values (3.30 for Epoxiconazole; 2.18 for Simazine; 3.70 for Tebuconazole) (Hijosa-Valsero et al. 2016; Zhang et al. 2016). Grab sampling allowed the detection of $44 \%$ of all target pesticides and the quantification of $31 \%$ (Fig.2B). Acetochlor and Alachlor were only quantified by POCIS. Conversely, Prosulfocarb was not quantified by POCIS, which can be attributed to the low sampling rate $\left(R_{S}=0.071 \mathrm{~L} \mathrm{~d}^{-1}\right)$ (Fig.2A). Retention of Prosulfocarb by POCIS is not favored and the concentration obtained was lower than the analytical LOQ. It should be noted that DET, by-products of 
1 terbuthylazine, was quantified only by the POCIS (5.00 ng L $\mathrm{L}^{-1}$, Table 3).Thus, passive

2 samplers could lead to a more representative level of contamination than that provided by

3 grab sampling and allowed us to measure low concentrations of pesticides (Lissalde et al.

4 2011; Poulier et al. 2015; Van Metre et al. 2017).

5 The most frequently detected and quantified compounds at all the study sites, were two

6 herbicides (Simazine, Chlortoluron), and two fungicides (Epoxiconazole, Tebuconazole) 7 regardless of the sampling technique (Fig.2 A and B). The high level of detection and 8 quantification of these compounds at the different sites by passive sampling (Fig.3) can be 9 explained by their intensive use in the treatment of crops in the Bizerte lagoon watershed. Indeed, Simazine is the active ingredient of "Agzozine", which is a pesticide sold in Tunisia to treat weeds and field crops, particularly legumes, one of the main crops cultivated in our survey areas. Epoxiconazole and Tebuconazole are the active ingredients most widely used by farmers to treat crops. Both are applied to wheat, barley and oats. They are used to control powdery mildew, helminthosporiasis, septoria and brown rust. Even if Chlortoluron is not inventoried in the list of active ingredients used for crops in the watershed, this substance was one of the major compounds detected during the sampling campaigns (up to $60 \%$ ). This compound is one of the active ingredients of two commercial products, "Dicuran 500" and "Tolurex 50" that are used to treat weeds and wild oats in wheat and barley fields; problably, it was used by farmers who were not interviewed in our survey.

\subsubsection{Space and time variations in concentrations of pesticides in water}

The total amount of pesticides (Epesticides), obtained by passive sampling and present at each sampling site, was used to assess the impact of the agricultural activity. The sum of pesticides ( $\sum$ pesticides) measured for all the seasons vary according to sites (Table 3). The highest concentration of $\sum$ pesticides was measured in Chegui oued (B): 1,246 ng L ${ }^{-1}$, and the lowest in Tinja oued (D): $35.9 \mathrm{ng} \mathrm{L}^{-1}$ (Table 3). The total concentrations of pollutants in Garaa 
1 oued (C) were close to $202.6 \mathrm{ng} \mathrm{L}^{-1}$. Among the oued sites, the least impacted sites were Tinja

2 (D) and Garaa (C) oueds. This may be due to the fact they are located in the downstream part

3 of the Bizerte lagoon watershed, and to the lesser presence of large agricultural areas around

4 them. Total pesticide concentrations in the lagoon itself were only $68 \mathrm{ng} \mathrm{L} \mathrm{L}^{-1}$; this low

5 concentration compared to the concentration in Chegui oued can be explained by the dilution

6 of the oued water in the lagoon (Carafa et al. 2007).

7 The intensity of agricultural activities is another argument to justify the high concentration of

8 target compounds in Chegui oued. According to the survey, wheat accounts for $60 \%$ of crops

9 grown at this site and legumes for 65\%. These crops are treated with herbicides and 10 fungicides, mainly Simazine and Tebuconazole. Our results are in agreement with the results 11 of previous studies showing that the highest concentrations of pesticides are generally 12 measured at sampling sites located in areas with a high proportion of arable land (Zhang et al. 13 2016).

14 Variations over time showed that the concentrations of $\sum$ pesticides vary with the season (Fig. 15 4). The high concentrations measured in the Chegui oued (B) compared to concentrations at 16 the other sites can be explained by its geographical and hydrological properties. Chegui oued 17 is located on the upstream side of the Bizerte lagoon catchment, the highest concentrations were found in Chegui oued in summer (B) $\left(832.5 \mathrm{ng} \mathrm{L}^{-1}\right)$; this could be due to the transport of pollutants from agricultural lands into the oued beacause of the rains, which drain the pesticides from crops to the sampling sites. Whereas, value of $413.8 \mathrm{ng} \mathrm{L}^{-1}$ was found in the spring season (Fig. 4). Concerning Garaa oued (C), the highest concentration was observed in spring (194.1 ng L $\left.{ }^{-1}\right)$. For site (A) and (D), the $\sum$ pesticides was very low regardless the season (e.g.concentrations were $20.8 \mathrm{ng} \mathrm{L}^{-1}$ in the spring in sites (A) and (D)). These results can be explained by the environmental conditions in these areas (solar radiation and water temperatures) (Bondarenko et al. 2004; Navarro et al. 2004; Carafa et al. 2007; Carvalho et al. 
1 2009). Temperature can affect the sorption rate of pollutants onto suspended matter and

2 organic matter ( $\mathrm{Wu}$ and Gschwend 1986). When temperatures increase, the solubility of the

3 compounds increases, and biodegradation and photodegradation are favored (Eriksson et al.

4 2003).

5 In the Mediterranean basin, the annual average global solar radiation reaching the surface is

$6168 \mathrm{~W} / \mathrm{m}^{2}$ (Chelbi et al. 2015). In Bizerte city (located in the study area), the annual average

7 global solar radiation is $208 \mathrm{~W} / \mathrm{m}^{2}$ (Ben Othman et al. 2018).

8 The most frequently measured compounds with high concentrations were Simazine and

9 Tebuconazole in the spring and summer in Chegui oued (B) (Table 3). This result is not surprising as these pesticides are mostly used to treat the wheat and legumes grown around this study site. The concentrations of Simazine found in spring and summer by passive sampling were $168 \mathrm{ng} \mathrm{L}^{-1}$ and $431.6 \mathrm{ng} \mathrm{L}^{-1}$, respectively (Table 3). The concentrations of Tebuconazole were $142 \mathrm{ng} \mathrm{L}^{-1}$ and $190.5 \mathrm{ng} \mathrm{L}^{-1}$ in spring and summer (Table 3). Moreover, the significant concentrations of fungicides (Tebuconazole, Epoxiconazole) in the spring can be explained by their application in April and May to protect wheat against fungal diseases such as septoria and rust.

The results suggest significant variations in concentrations as a function of the agricultural seasons. For example, herbicides are widely applied to field crops, particularly legumes and wheat, in spring and autumn. This explains the abundance of herbicides at the study sites during these periods and a few months after they were sprayed in the fields (Zhang et al. 2016).

Pesticide concentrations (obtained by grab sampling) (Table 4) are in agreement with those obtained by POCIS (Table 3). Indeed, the highest concentration of DIA, Simazine, Tebuconazole, and Epoxiconzole were observed in spring even for Chegui oued (B), Garaa oued (C). 
1 Simazine was mainly found in spring in Chegui oued (B), Garaa oued (C) and Tinja oued (D)

2 with concentrations of $730.9 \mathrm{ng} \mathrm{L}^{-1}, 56.9 \mathrm{ng} \mathrm{L}^{-1}$ and $32.5 \mathrm{ng} \mathrm{L}^{-1}$, respectively (Table 4). These

3 values are below than those of the existing Quality Standards in Directive 2013/39 / EU of the

4 European Parliament and the Council of 12 August $2013\left(1 \mu \mathrm{g} \mathrm{L}^{-1}\right)$ (EU 2013). The

5 concentrations of Tebuconazole in the same season and at the same sites were $500.3 \mathrm{ng} \mathrm{L}^{-1}$,

$6 \quad 178.4 \mathrm{ng} \mathrm{L}^{-1}$ and $56.5 \mathrm{ng} \mathrm{L}^{-1}$, respectively (Table 4). According to previous studies, for a

7 representative diagnosis of pesticide occurrence, POCIS and spot sampling should be used as

8 a complement to grab sampling (Poulier et al. 2014; Miège et al. 2015, Branchet et al. 2018).

9 Passive sampling is recommended by water policy in the European Commission Guidance Document (EC Guidance document n ${ }^{\circ}$ 19) and in Directive 2013/39/EU (EU 2013).

Additionally, the results of monitoring of the water column by passive and grab sampling confirmed those of the survey (Table 3, Table 4). Indeed, screening revealed some pesticides identified during the survey, including Simazine, Tebuconazole, Prosulfocarb, and Epoxiconazole. These are among the compounds most widely used by farmers to treat wheat. 3.3 Occurrence and variations in pesticide concentrations in sediments in space and over time 3.3.1 Occurrence of pesticides in sediments

Studying the composition of coastal sediments is one of the main ways used to identify the level and source of contamination of marine ecosystems (Zaghden et al. 2017). Indeed, sediments are known to trap hydrophobic contaminants, particularly non-polar pesticides like chlorinated compounds (Meakins et al. 1995). Consequently, sediments were also investigated to complete the diagnosis of the contamination of the Bizerte lagoon watershed by agricultural pesticides. The detection and quantification frequencies of the targeted compounds during the three campaigns and at the four study sites are summarized in Fig. 5. No compounds were quantified in Tinja oued (D). The most impacted sediments were those of Chegui oued (B) and Garaa oued (C). The majority of the targeted compounds, e.g. 
1 Alachlor, Acetochlor, Metolachlor, were detected at a frequency of 34\%. Prosulfocarb,

2 Epoxiconazole and Tebuconazole were detected at a frequency of $100 \%$ in the Chegui and

3 Garaa oueds. These compounds were also quantified at these two sites (B and C). Indeed,

4 Prosulfocarb was quantified at frequencies of $100 \%$ and $34 \%$ in Garaa oued (C) and Chegui

5 oued (B), respectively. However, Tebuconazole and Epoxionazole were quantified at

6 frequencies of $100 \%$ and $68 \%$ in Chegui oued (B) and Garaa oued (C), respectively.

$7 \quad$ 3.3.2 Space and time variations in the concentration of pesticide in sediments

8 The sum of pesticides ( pesticides) in the sediments of the watershed of the Bizerte lagoon

9 ranged from $9.8 \mathrm{ng} \mathrm{g}^{-1} \mathrm{dw}$ in the lagoon (A) to $53 \mathrm{ng} \mathrm{g}^{-1} \mathrm{dw}$ in the Chegui oued (C) (Table 5). Particle size is an important parameter to consider when analyzing sediment samples (Ackermann 2008). In the present study, the percentage of fine particles $(<63 \mu \mathrm{m})$ in the sediments differed at each site, varying from $12 \%$ to $69 \%$ in the lagoon (A), from $62 \%$ to $77 \%$ in Chegui oued (B), from $94 \%$ to $100 \%$ in Garaa oued, and from $11 \%$ to $57 \%$ in Tinja oued (D) (Table 5). In spring saison, the higher total concentration of pesticides in Chegui oued sediments $\left(31.1 \mathrm{ng}^{-1}\right.$ ), can be explained by the higher content of fine particles; the large surface area available (per unit of mass) of the small particles increases the adsorption of pollutants onto the grains (Gao et al. 1998). Additionally, fine sediment particles may accumulate pesticides due to their mineral compounds (e.g, silicate, goethite and hematite, montmorillonite, iron oxides, manganese oxides, illite, etc). No apparent relationship was found between TOC and grain size $(<63 \mu \mathrm{m})$ at the sites analyzed $(\mathrm{p}>0.05, \mathrm{n}=12)$. In addition, no significant correlations were found between TOC content, grain size $(<63 \mu \mathrm{m})$ and the majority of compounds analyzed. This implies that the distributions and concentrations of pesticides are not only determined by sedimentary characteristics such as TOC and grain size (Mai et al. 2005), but probably by other factors such as sources, transport, mixing, and deposition that were not analyzed in this study. 
1 Table 5 reports the individual concentration of pesticides, the highest concentration of

2 Tebuconazole was found in Chegui oued (B) in spring (31.1 $\mathrm{ng} \mathrm{g}^{-1}$, dw) (Table 5). The

3 highest concentration of Prosulfocarb (6.3 $\mathrm{ng} \mathrm{g}^{-1} \mathrm{dw}$ ) was measured in Garaa oued (C) in

4 autumn. A relatively high $\log K_{o w}$ (octanol/water coefficient) means that polluants can be

5 strongly adsorbed onto sediments particules and organic matter (PAPP 2010). For

6 Tebuconazole and Prosulfocarb, $\log K_{o w}$ values were 3.70 and 4.48, respectively (INERIS

7 2011, 2013), these values indicate that Tebuconazole and Prosulfocarb are sorbed to

8 sediments (Chamberlain et al. 1996; Čadková et al. 2013).

93.4 Space time variations in pesticide concentrations in the Bizerte lagoon watershed

10 These results reveal a space-time variation in pesticide concentrations in the water column

11 and in the sediments in the Bizerte lagoon watershed. These results show that among the 12 pesticides found in the sediments and water, 60\% are approved for use in Tunisia (20\% 13 herbicides, $36 \%$ fungicides, $4 \%$ insecticides).

14 These results are in agreement with those of Jiménez et al. (1999), who showed that pesticide 15 concentrations in water and sediments were subject to seasonal variations in 27 Mediterranean 16 lakes. Moreover, the presence and distribution of pesticides in the water and/or in the 17 sediments depends on the physical-chemical properties of the compounds $\left(\log K_{\text {ow }}\right.$ and water solubility). Some of the pesticides (e.g, Atrazine, Diuron) found in the water at the sites we investigated are not yet approved for use in Tunisia. These herbicides (Atrazine, Diuron) pose a serious risk for aquatic ecosystems as well as for the environment (Moncada 2004; RalstonHooper et al. 2009).

Literature on levels of polar pesticides in samples of water is scarce (in particular on fungicides and herbicides), making it difficult to compare our results with those obtained elsewhere in the world. In sediments, the studied pesticides are mainly the organochlorines (Barhoumi 2014; Ben Salem et al. 2016). The concentrations of total pesticides in water and 
1 sediments in the lagoon and oueds were lower than those measured in Mondego River Estuary

2 in Portugal (Cruzeiro et al. 2016), Ria Formosa lagoon in Portugal (Cruzeiro et al. 2015),

3 Tagus River basin in Greece (Papadakis et al. 2015), in a river basin in Costa Rica (Carazo-

4 Rojas et al. 2018) and in Méfou watershed in Cameroon (Branchet et al. 2018). However, the

5 concentrations we measured were higher than those measured in the Arade River estuary in

6 Portugal (Gonzalez-Rey et al. 2015), in the River Ugie in Scotland (Zhang et al. 2016) and in

7 the Marque River in France (Criquet et al. 2017).

8 The concentrations of total pesticides in the lagoon and oued sediments studied here are lower

9 than those reported in Mediterranean coastal lagoons in SE Spain (Moreno-González and 10 León 2017).

\section{4. Conclusion}

This study highlights a worrying issue that affects the majority of Mediterranean lagoons: human pressure, especially agricultural pollution. The Bizerte lagoon is one of the most affected by this anthropization in particular by agriculture activities, justifying our investigation of the occurrence of herbicides and fungicides. This study confirmed contamination by polar pesticides (herbicides and fungicides) in the watershed and in the lagoon ecosystem. Analyses of samples from the four sampling sites revealed the highest contaminations in the water and sediments of Chegui oued. The results of our analyses are in agreement with survey data: several molecules (including Simazine, Tebuconazole and Prosulfocarb) were found at the target sites. Simazine and Tebuconazole molecules, the most significant species present in the water samples, were identified by passive sampling at a maximum concentration of $431.6 \mathrm{ng} \mathrm{L}^{-1}$ and $190.5 \mathrm{ng} \mathrm{L}^{-1}$ in the Chegui oued, respectively. The molecule found at the highest concentrations in the sediments was Tebuconazole (31.1 ng $\mathrm{g}^{-1}, \mathrm{dw}$ ) and although Prosulfocarb was detected in trace amounts in the water samples, a concentration of $6.3 \mathrm{ng} \mathrm{g}^{-1} \mathrm{dw}$ was found in the sediments of the Garaa oued. The POCIS 
1 technique was used for the first time in Tunisia and was shown to improve the analysis of the

2 trace concentrations of polar pollutants. The results of this work support the hypothesis that

3 the ability of passive samplers (POCIS) to integrate the contaminant concentrations over a

4 period of exposure enables better quantification of contamination at low concentrations.

\section{Acknowledgements}

6 This study was financed by LMI Cosy-MED (IRD), Institut Mines Télécom Mines Alès and 7 the Tunisian Ministry of Higher Education and Scientific Research (Carthage University),

8 The authors would like to thank the Tunisian farmers and fishermen of Bizerte for their kind 9 assistance in the monitoring studies.

10 References

11 (FAO) F and AO (2015) Mediterranean coastal lagoons: sustainable management and interactions among aquaculture, cpture fisheries and the environment

(UNEP) UNEP (2001) Stockholm Covention on Persistent Organic Pollutants (POPs). Secr Stock Conv Persistent Org Pollut 56

Ackermann F (2008) A procedure for correcting the grain size effect in heavy metal analyses of estuarine and coastal sediments A PROCEDURE FOR CORRECTING THE GRAIN SIZE EFFECT IN HEAVY METAL ANALYSES OF. 37-41

Ahrens L, Daneshvar A, Lau AE, Kreuger J (2015) Characterization of five passive sampling devices for monitoring of pesticides in water. J Chromatogr A 1405:1-11. doi: 10.1016/j.chroma.2015.05.044

Arellano-Aguilar O, Betancourt-Lozano M, Aguilar-Zárate G, Ponce de Leon-Hill C (2017) Agrochemical loading in drains and rivers and its connection with pollution in coastal lagoons of the Mexican Pacific. Environ Monit Assess 189:189-270. doi: $10.1007 / \mathrm{s} 10661-017-5981-8$

Barhoumi B (2014) Biosurveillance de la pollution de la lagune de Bizerte ( Tunisie ) par 1' 
analyse compar ' ee des niveaux de contamination et de 1' ' ecotoxicit ' e des s ' ediments et du biote Badreddine Barhoumi To cite this version :

Barhoumi B, El Megdiche Y, Clérandeau C, et al (2016) Occurrence of polycyclic aromatic hydrocarbons (PAHs) in mussel (Mytilus galloprovincialis) and eel (Anguilla anguilla) from Bizerte lagoon, Tunisia, and associated human health risk assessment. Cont Shelf Res 124:104-116. doi: 10.1016/j.csr.2016.05.012

Barhoumi B, Lemenach K, Devier MH, et al (2014) Polycyclic aromatic hydrocarbons (PAHs) in surface sediments from the Bizerte Lagoon, Tunisia: Levels, sources, and toxicological significance. Environ Monit Assess 186:2653-2669. doi: 10.1007/s10661013-3569-5

Barhoumi B, LeMenach K, Dévier MH, et al (2013) Distribution and ecological risk of polychlorinated biphenyls (PCBs) and organochlorine pesticides (OCPs) in surface sediments from the Bizerte lagoon, Tunisia. Environ Sci Pollut Res 21:6290-6302. doi: $10.1007 / \mathrm{s} 11356-013-1709-7$

Béjaoui B, Harzallah A, Moussa M, et al (2008) Analysis of hydrobiological pattern in the Bizerte lagoon (Tunisia). Estuar Coast Shelf Sci 80:121-129. doi: 10.1016/j.ecss.2008.07.011

Belmonte Vega A, Garrido Frenich A, Martínez Vidal JL (2005) Monitoring of pesticides in agricultural water and soil samples from Andalusia by liquid chromatography coupled to mass spectrometry. Anal Chim Acta 538:117-127. doi: 10.1016/j.aca.2005.02.003

Ben Othman A, Belkilani K, Besbes M (2018) Global solar radiation on tilted surfaces in Tunisia: Measurement, estimation and gained energy assessments. Energy Reports 4:101-109. doi: 10.1016/j.egyr.2017.10.003

Ben Said, Said O Ben, Goñi-Urriza M, et al (2010) Bacterial community structure of sediments of the bizerte lagoon (Tunisia), a southern mediterranean coastal anthropized 
Ben Salem F Ben, Said O Ben, Aissa P, et al (2016) Pesticides in Ichkeul Lake-Bizerta Lagoon Watershed in Tunisia: use, occurrence, and effects on bacteria and free-living marine nematodes. Environ Sci Pollut Res 23:36-48. doi: 10.1007/s11356-015-4991-8

Ben Salem F (2017) First Survey of Agricultural Pesticides Used for Crops in Ichkeul LakeBizerte Lagoon Watershed ( Tunisia ). 13:1-10

Bondarenko S, Gan J, Haver DL, Kabashima JN (2004) Persistence of selected organophosphate and carbamate insecticides in waters from a coastal watershed. Environ Toxicol Chem 23:2649-2654. doi: 10.1897/03-436

Boonyatumanond R, Jaksakul A, Puncharoen P, Tabucanon MS (2002) Monitoring of organochlorine pesticides residues in green mussels (Perna viridis) from the coastal area of Thailand. Environ Pollut 119:245-252. doi: 10.1016/S0269-7491(01)00329-3

Botta F, Lavison G, Couturier G, et al (2009) Transfer of glyphosate and its degradate AMPA to surface waters through urban sewerage systems. Chemosphere 77:133-139. doi: 10.1016/j.chemosphere.2009.05.008

Branchet P, Cadot E, Fenet H, et al (2018) Polar pesticide contamination of an urban and periurban tropical watershed affected by agricultural activities (Yaoundé, Center Region, Cameroon). Environ Sci Pollut Res 25:17690-17715. doi: 10.1007/s11356-018-1798-4

Čadková E, Komárek M, Kaliszová R, et al (2013) Tebuconazole Sorption in Contrasting Soil Types. Soil Sediment Contam 22:404-414. doi: 10.1080/15320383.2013.733448

Carabias-Martínez R, Rodríguez-Gonzalo E, Herrero-Hernández E, et al (2002) Determination of herbicides and metabolites by solid-phase extraction and liquid chromatography - Evaluation of pollution due to herbicides in surface and groundwaters. J Chromatogr A 950:157-166. doi: 10.1016/S0021-9673(01)01613-2

Carafa R, Wollgast J, Canuti E, et al (2007) Seasonal variations of selected herbicides and 
related metabolites in water, sediment, seaweed and clams in the Sacca di Goro coastal lagoon (Northern Adriatic). Chemosphere 69:1625-1637. doi: 10.1016/j.chemosphere.2007.05.060

Carazo-Rojas E, Pérez-Rojas G, Pérez-Villanueva M, et al (2018) Pesticide monitoring and ecotoxicological risk assessment in surface water bodies and sediments of a tropical agro-ecosystem. Environ Pollut 241:800-809. doi: 10.1016/j.envpol.2018.06.020

Carro N, Cobas J, García I, et al (2014) Distribution and trend of organochlorine pesticides in galicia coast using mussels as bioindicator organisms. Possible relationship to biological parameters. Chemosphere 102:37-47. doi: 10.1016/j.chemosphere.2013.12.010

Carvalho FP, Villeneuve JP, Cattini C, et al (2009) Pesticide and PCB residues in the aquatic ecosystems of Laguna de Terminos, a protected area of the coast of Campeche, Mexico. Chemosphere 74:988-995. doi: 10.1016/j.chemosphere.2008.09.092

Chamberlain K, Evans AA, Bromilow RH (1996) 1-Octanol/Water Partition Coefficient (K ow ) and $\mathrm{pK}_{\mathrm{a}}$ for Ionisable Pesticides Measured by apH-Metric Method. Pestic Sci 47:265271. doi: 10.1002/(SICI)1096-9063(199607)47:3<265::AID-PS416>3.0.CO;2-F

Charlestra L, Amirbahman A, Courtemanch DL, et al (2012) Estimating pesticide sampling rates by the polar organic chemical integrative sampler (POCIS) in the presence of natural organic matter and varying hydrodynamic conditions. Environ Pollut 169:98104. doi: 10.1016/j.envpol.2012.05.001

Chelbi M, Gagnon Y, Waewsak J (2015) Solar radiation mapping using sunshine durationbased models and interpolation techniques: Application to Tunisia. Energy Convers Manag 101:203-215. doi: 10.1016/j.enconman.2015.04.052

Comoretto L, Chiron S (2005) Comparing pharmaceutical and pesticide loads into a small Mediterranean river. Sci Total Environ 349:201-210. doi: 10.1016/j.scitotenv.2005.01.036 
1 Criquet J, Dumoulin D, Howsam M, et al (2017) Comparison of POCIS passive samplers vs.

2

3

4

5

6

8 Cruzeiro C, Rocha E, Ângelo M, João M (2016) Environmental assessment of pesticides in

composite water sampling: A case study. Sci Total Environ 609:982-991. doi: 10.1016/j.scitotenv.2017.07.227

Cruzeiro C, Pardal MÂ, Rocha E, Rocha MJ (2015) Occurrence and seasonal loads of pesticides in surface water and suspended particulate matter from a wetland of worldwide interest — the Ria Formosa Lagoon , Portugal. doi: 10.1007/s10661-015$4824-8$ the Mondego River Estuary ( Portugal ). doi: 10.1016/j.marpolbul.2015.12.013

De Gerónimo E, Aparicio VC, Bárbaro S, et al (2014) Presence of pesticides in surface water from four sub-basins in Argentina. Chemosphere 107:423-431. doi:

10.1016/j.chemosphere.2014.01.039

Desgranges N (2015) Développement d'échantillonneurs passifs de type POCIS pour

l'évaluation de la contamination en pesticides des eaux de bassins versants languedociens. Université de Bordeaux

Dujaković N, Grujić S, Radišić M, et al (2010) Determination of pesticides in surface and ground waters by liquid chromatography-electrospray-tandem mass spectrometry. Anal Chim Acta 678:63-72. doi: 10.1016/j.aca.2010.08.016

Eriksson M, Sodersten E, Yu Z, et al (2003) Degradation of Polycyclic Aromatic Hydrocarbons at Low Temperature under Aerobic and Nitrate-Reducing Conditions in Enrichment Cultures from Northern Soils Degradation of Polycyclic Aromatic Hydrocarbons at Low Temperature under Aerobic and Nitrate-Reduci. Society 69:275284. doi: 10.1128/AEM.69.1.275

ESF-Marine Board (2011) ESF-Marine Board European Scientific Diving Panel activities EU (2008) Directive 2008/105/CE of the European Parliament and of the Council of 16 
2 the field of water policy. 84-97

3 EU (2013) Directive 2013/39/EU of the European Parliament and of the Council of 12 August 2013 amending Directives 2000/60/EC and 2008/105/EC as regards priority substances in the field of water policy

Gao JP, Maguhn J, Spitzauer P, Kettrup A (1998) Sorption of pesticides in the sediment of the Teufelsweiher pond (Southern Germany). I: Equilibrium assessments, effect of organic carbon content and pH. Water Res 32:1662-1672. doi: 10.1016/S0043-1354(97)00377-1

Gonzalez-Rey M, Tapie N, Le Menach K, et al (2015) Occurrence of pharmaceutical compounds and pesticides in aquatic systems. Mar Pollut Bull 96:384-400. doi: 10.1016/j.marpolbul.2015.04.029

Greenwood R, Mills G, Vrana B (2007) Passive sampling techniques in environmental monitoring. Elsevier, Amsterdam; Oxford

Guo W, Zhang H, Huo S (2014) Organochlorine pesticides in aquatic hydrophyte tissues and surrounding sediments in Baiyangdian wetland, China. Ecol Eng 67:150-155. doi: 10.1016/j.ecoleng.2014.03.047

Hamilton DJ, Ambrus Á, Dieterle RM, et al (2003) Regulatory limits for pesticide residues in water (IUPAC Technical Report). Pure Appl Chem 75:1123-1155. doi: $10.1351 /$ pac200375081123

Herceg-Romanić S, Kljaković-Gašpic Z, Klinčić D, Ujević I (2014) Distribution of persistent organic pollutants (POPs) in cultured mussels from the Croatian coast of the Adriatic Sea. Chemosphere 114:69-75. doi: 10.1016/j.chemosphere.2014.04.017

Hijosa-Valsero M, Bécares E, Fernández-Aláez C, et al (2016) Chemical pollution in inland shallow lakes in the Mediterranean region (NW Spain): PAHs, insecticides and herbicides in water and sediments. Sci Total Environ 544:797-810. doi: 
Ibrahim I, Togola A, Gonzalez C (2013a) Polar organic chemical integrative sampler (POCIS) uptake rates for 17 polar pesticides and degradation products: laboratory calibration. Environ Sci Pollut Res 20:3679-3687. doi: 10.1007/s11356-012-1284-3

5 Ibrahim I, Togola A, Gonzalez C (2013b) In-situ calibration of POCIS for the sampling of 6 polar pesticides and metabolites in surface water. Talanta 116:495-500. doi:

7 10.1016/j.talanta.2013.07.028

INERIS (2011) Environmental quality standards forTebuconazole

INERIS (2013) Environmental guide value for Prosulfocarb - $\mathrm{n}{ }^{\circ}$ CAS : 52888-80-9

Jiménez JJ, Bernal JL, Rivera JM, et al (1999) Seasonal changes in the contents of widely used pesticides in waters and sediments from small lakes in the province of Leon (Spain). Toxicol Environ Chem 70:57-66. doi: 10.1080/02772249909358739

Kaushik A, Sharma HR, Jain S, et al (2010) Pesticide pollution of River Ghaggar in Haryana, India. Environ Monit Assess 160:61-69. doi: 10.1007/s10661-008-0657-z

Khaled A, El Nemr A, Said TO, et al (2004) Polychlorinated biphenyls and chlorinated pesticides in mussels from the Egyptian Red Sea coast. Chemosphere 54:1407-1412. doi: $10.1016 /$ j.chemosphere.2003.10.042

Kuster M, López de Alda MJ, Hernando MD, et al (2008) Analysis and occurrence of pharmaceuticals, estrogens, progestogens and polar pesticides in sewage treatment plant effluents, river water and drinking water in the Llobregat river basin (Barcelona, Spain). J Hydrol 358:112-123. doi: 10.1016/j.jhydrol.2008.05.030

Li Y, Niu J, Shen Z, et al (2014) Spatial and seasonal distribution of organochlorine pesticides in the sediments of the Yangtze Estuary. Chemosphere 114:233-240. doi: 10.1016/j.chemosphere.2014.04.112

Liess M, Schulz R, Liess MHD, et al (1999) Determination of insecticide contamination in 


\section{2 1354(98)00174-2}

3 Lissalde S, Mazzella N, Fauvelle V, et al (2011) Liquid chromatography coupled with tandem mass spectrometry method for thirty-three pesticides in natural water and comparison of performance between classical solid phase extraction and passive sampling approaches. $\mathbf{J}$ Chromatogr A 1218:1492-1502. doi: 10.1016/j.chroma.2011.01.040

Lissalde S, Mazzella N, Mazellier P (2014) Polar organic chemical integrative samplers for pesticides monitoring: Impacts of field exposure conditions. Sci Total Environ 488489:188-196. doi: 10.1016/j.scitotenv.2014.04.069

Macdonald RW, Harner T, Fyfe J (2005) Recent climate change in the Arctic and its impact on contaminant pathways and interpretation of temporal trend data. Sci Total Environ 342:5-86. doi: 10.1016/j.scitotenv.2004.12.059

Mai B, Chen S, Luo X, et al (2005) Distribution of polybrominated diphenyl ethers in sediments of the Pearl River Delta and adjacent South China Sea. Environ Sci Technol 39:3521-3527. doi: 10.1021/es048083x

Maloschik E, Ernst A, Hegedus G, et al (2007) Monitoring water-polluting pesticides in Hungary. Microchem J 85:88-97. doi: 10.1016/j.microc.2006.05.002

Martínez Bueno MJ, Herrera S, Munaron D, et al (2014) POCIS passive samplers as a monitoring tool for pharmaceutical residues and their transformation products in marine environment. Environ Sci Pollut Res 23:5019-5029. doi: 10.1007/s11356-014-3796-5

Meakins NC, Bubb JM, Lester JN (1995) The mobility, partitioning and degradation of atrazine and simazine in the salt marsh environment. Mar Pollut Bull 30:812-819. doi: 10.1016/0025-326X(95)00074-W

Mezghani et al. (2016) Liste des pesticides Homologués

Miège C, Budzinski H, Jacquet R, et al (2013) Polar organic chemical integrative sampler

agricultural headwater streams. Water Res 33:239-247. doi: 10.1016/S0043- 
1

(POCIS): Application for monitoring organic micropollutants in wastewater effluent and surface water. J Environ Monit 14:626-635. doi: 10.1039/c1em10730e

Miège C, Mazzella N, Allan I, et al (2015) Position paper on passive sampling techniques for the monitoring of contaminants in the aquatic environment - Achievements to date and perspectives. Trends Environ Anal Chem 8:20-26. doi: 10.1016/j.teac.2015.07.001

Momplaisir GM, Rosal CG, Heithmar EM, et al (2010) Development of a solid phase extraction method for agricultural pesticides in large-volume water samples. Talanta 81:1380-1386. doi: 10.1016/j.talanta.2010.02.038

Moncada A (2004) Environmental Fate of Diuron. Ground Water

Moreno-González R, León VM (2017) Presence and distribution of current-use pesticides in surface marine sediments from a Mediterranean coastal lagoon (SE Spain). Environ Sci Pollut Res 24:8033-8048. doi: 10.1007/s11356-017-8456-0

Mzoughi N, Hellal F, Dachraoui M, et al (2002) Méthodologie de l'extraction des hydrocarbures aromatiques polycycliques. Application à des sédiments de la lagune de Bizerte (Tunisie). Comptes Rendus - Geosci 334:893-901. doi: 10.1016/S16310713(02)01827-8

Mzoughi N, Lespes G, Bravo M, et al (2005) Organotin speciation in Bizerte lagoon (Tunisia). Sci Total Environ 349:211-222. doi: 10.1016/j.scitotenv.2004.12.067

Navarro S, Vela N, José Giménez M, Navarro G (2004) Effect of temperature on the disappearance of four triazine herbicides in environmental waters. Chemosphere 57:5159. doi: 10.1016/j.chemosphere.2004.05.016

Necibi M, Mzoughi N, Néjib Daly Yahia M, Pringault O (2015) Distributions of organochlorine pesticides and polychlorinated biphenyl in surface water from Bizerte Lagoon, Tunisia. Desalin Water Treat 56:2663-2671. doi: $10.1080 / 19443994.2015 .1024935$ 
1 Nefzaoui A, Ketata H, El-Mourid M (2012) Changes in North Africa production systems to meet climate uncertainty and new socio-economic scenarios with a focus on dryland areas. Options Mediterr Ser A, Semin Mediterr 421:403-421

Ouertani N, Hamouda R, Belayouni H (2006) Etude de la mati??re organique dans les s??diments superficiels d'un syst??me aquatique confin?? anoxique ??voluant en milieu urbain: Cas du Lac sud de Tunis. Geo Eco Trop 30:21-34

Palma P, Köck-Schulmeyer M, Alvarenga P, et al (2014) Risk assessment of pesticides detected in surface water of the Alqueva reservoir (Guadiana basin, southern of Portugal). Sci Total Environ 488-489:208-219. doi: 10.1016/j.scitotenv.2014.04.088

Papadakis EN, Vryzas Z, Kotopoulou A, et al (2015) Ecotoxicology and Environmental Safety A pesticide monitoring survey in rivers and lakes of northern Greece and its human and ecotoxicological risk assessment. Ecotoxicol Environ Saf 116:1-9. doi: 10.1016/j.ecoenv.2015.02.033

PAPP R (2010) Les propriétés ENVIRONNEMENTALES des substances. 1-126

Poulier G, Lissalde S, Charriau A, et al (2014) Can POCIS be used in Water Framework Directive (2000/60/EC) monitoring networks? A study focusing on pesticides in a French agricultural watershed. Sci Total Environ 497-498:282-292. doi: 10.1016/j.scitotenv.2014.08.001

Poulier G, Lissalde S, Charriau A, et al (2015) Estimates of pesticide concentrations and fluxes in two rivers of an extensive French multi-agricultural watershed: application of the passive sampling strategy. Environ Sci Pollut Res 22:8044-8057. doi: 10.1007/s11356-014-2814-y

Ralston-Hooper K, Hardy J, Hahn L, et al (2009) Acute and chronic toxicity of atrazine and its metabolites deethylatrazine and deisopropylatrazine on aquatic organisms. Ecotoxicology 18:899-905. doi: 10.1007/s10646-009-0351-0 
1 Savinov V (2000) Polycyclic Aromatic Hydrocarbons (PAHs) in Sediments of the White Sea,

Russia. Mar Pollut Bull 40:807-818. doi: 10.1016/S0025-326X(00)00004-7

Terzopoulou E, Voutsa D (2016) Active and passive sampling for the assessment of hydrophilic organic contaminants in a river basin-ecotoxicological risk assessment. Environ Sci Pollut Res 23:5577-5591. doi: 10.1007/s11356-015-5760-4

Van Metre PC, Alvarez DA, Mahler BJ, et al (2017) Complex mixtures of Pesticides in Midwest U.S. streams indicated by POCIS time-integrating samplers. Environ Pollut 220:431-440. doi: 10.1016/j.envpol.2016.09.085

Vryzas Z, Vassiliou G, Alexoudis C, Papadopoulou-Mourkidou E (2009) Spatial and temporal distribution of pesticide residues in surface waters in northeastern Greece. Water Res 43:1-10. doi: 10.1016/j.watres.2008.09.021

Wu SC, Gschwend PM (1986) Sorption kinetics of hydrophobic organic compounds to natural sediments and soils. Environ Sci Technol 20:717-725. doi: 10.1021/es00149a011

Xue N, Xu X, Jin Z (2005) Screening 31 endocrine-disrupting pesticides in water and surface sediment samples from Beijing Guanting reservoir. Chemosphere 61:1594-1606. doi: 10.1016/j.chemosphere.2005.04.091

Yabuki Y, Nagai T, Inao K, et al (2016) Temperature dependence on the pesticide sampling rate of polar organic chemical integrative samplers (POCIS). Biosci Biotechnol Biochem 80:2069-2075. doi: 10.1080/09168451.2016.1191329

Yohannes YB, Ikenaka Y, Saengtienchai A, et al (2014) Concentrations and human health risk assessment of organochlorine pesticides in edible fish species from a Rift Valley lake-Lake Ziway, Ethiopia. Ecotoxicol Environ Saf 106:95-101. doi: 10.1016/j.ecoenv.2014.04.014

Zaghden H, Tedetti M, Sayadi S, et al (2017) Origin and distribution of hydrocarbons and organic matter in the surficial sediments of the Sfax-Kerkennah channel (Tunisia, 
1 Southern Mediterranean Sea). Mar Pollut Bull 117:414-428. doi:

1

2 10.1016/j.marpolbul.2017.02.007

3 Zhang J, Liu F, Chen R, et al (2012) Levels of polychlorinated biphenyls and organochlorine 4 pesticides in edible shellfish from Xiamen (China) and estimation of human dietary intake. Food Chem Toxicol 50:4285-4291. doi: 10.1016/j.fct.2012.08.052

6 Zhang Z, Troldborg M, Yates K, et al (2016) Evaluation of spot and passive sampling for 7 monitoring, flux estimation and risk assessment of pesticides within the constraints of a 8 typical regulatory monitoring scheme. Sci Total Environ 569-570:1369-1379. doi:

9 10.1016/j.scitotenv.2016.06.219 


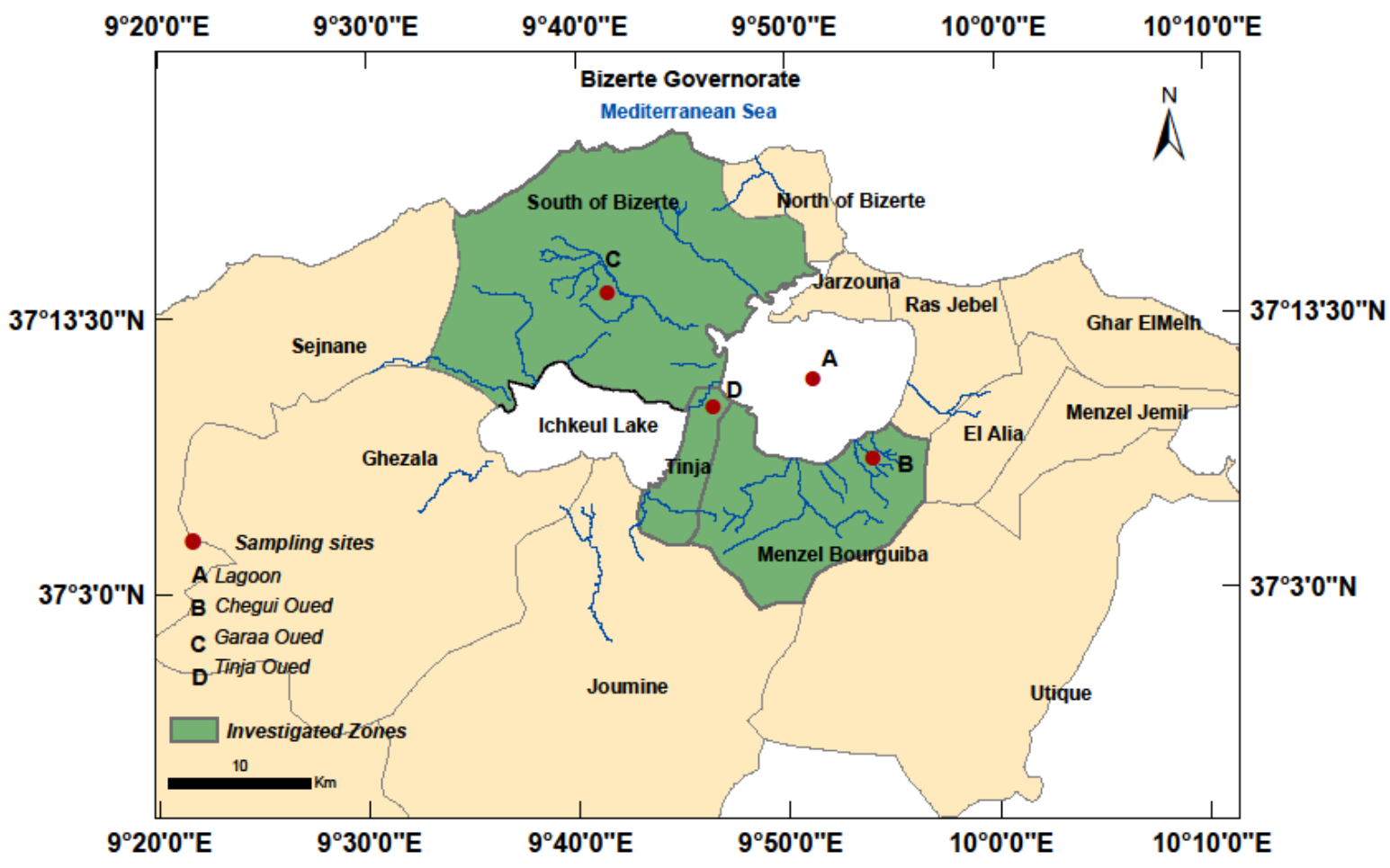

Fig. 1 Study zones and sampling sites (A: lagoon, B: Chegui oued, C: Garaa oued and D:

Tinja oued) in the Bizerte lagoon watershed 
A

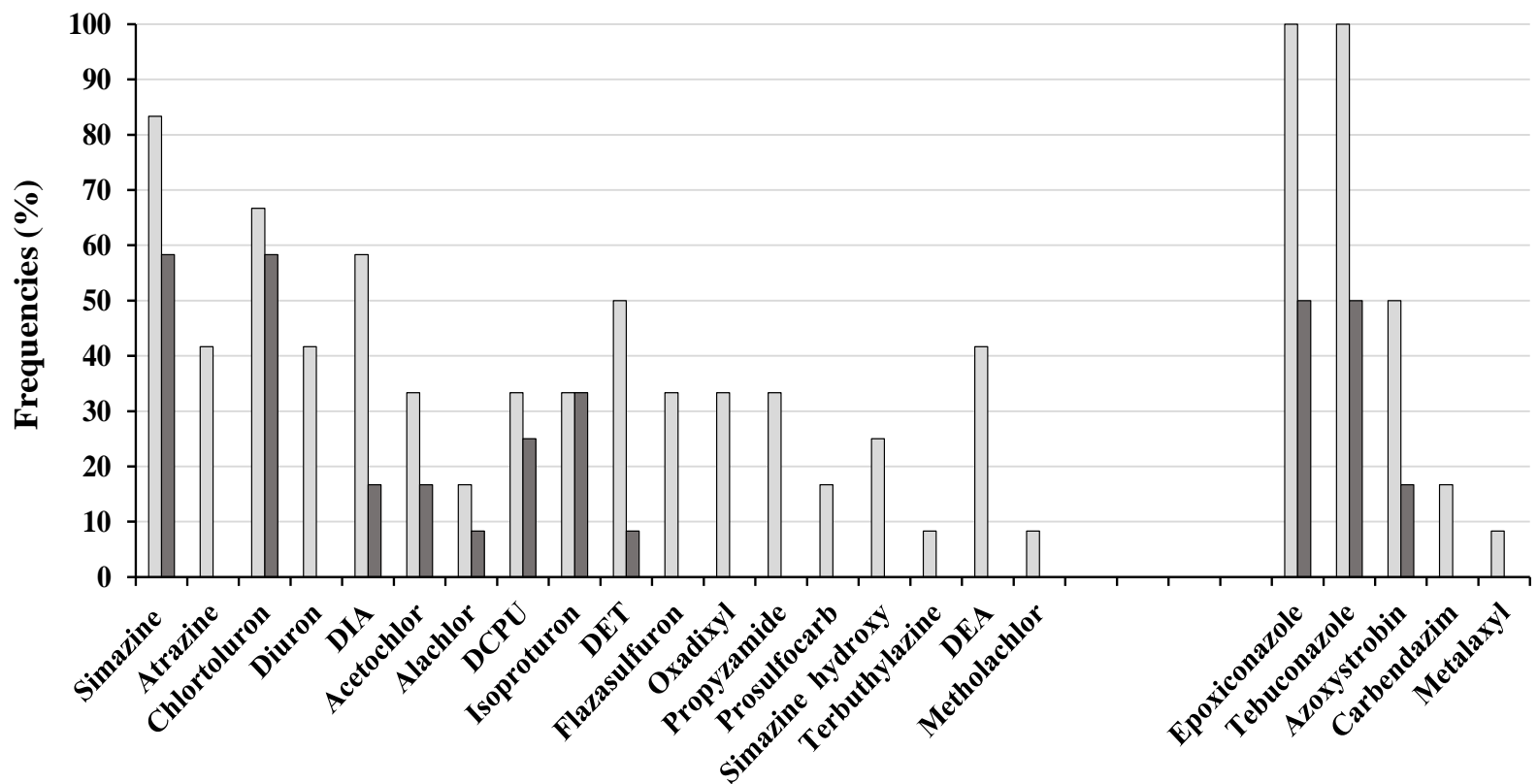

B

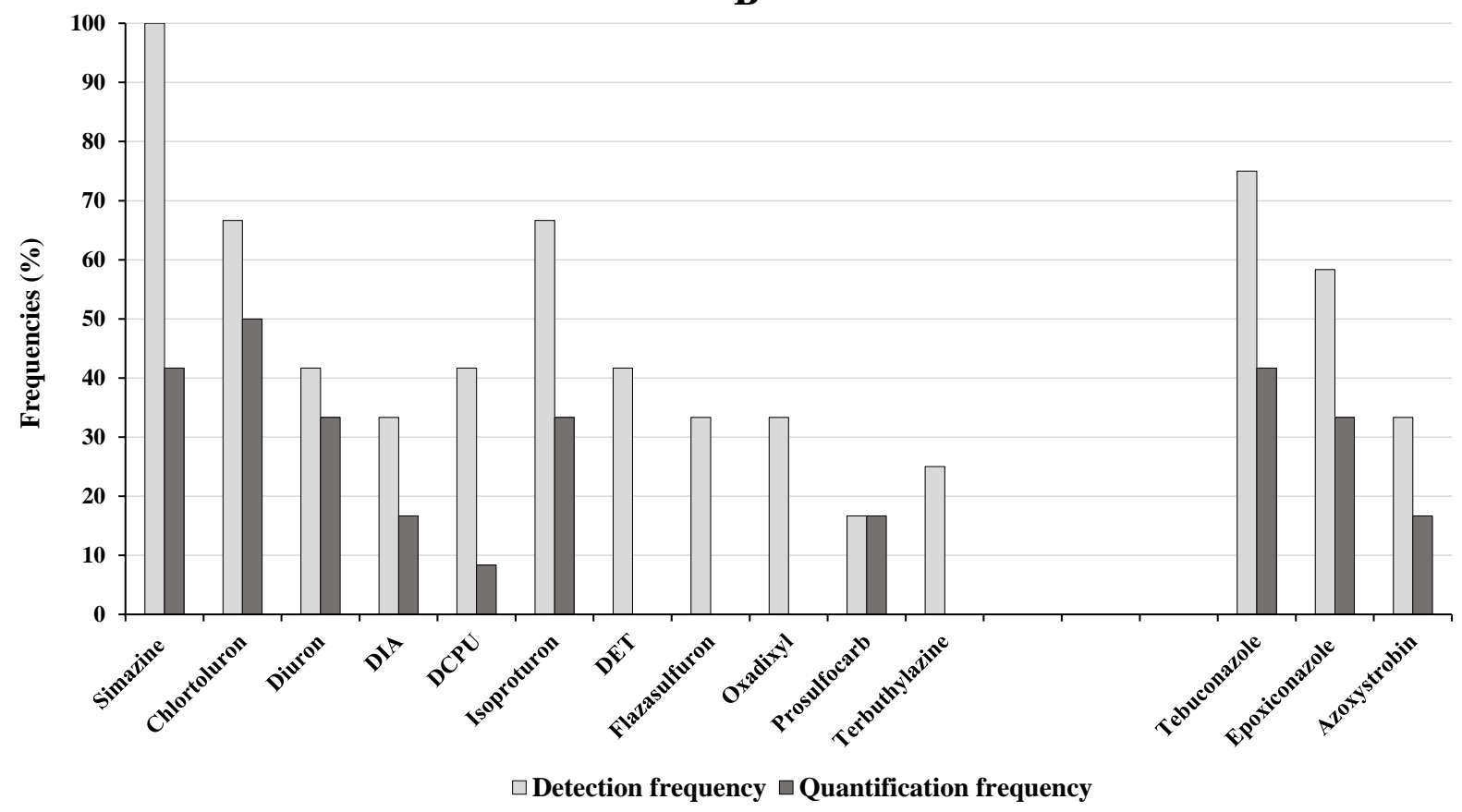

Fig.2 Global detection and quantification frequencies obtained by passive sampling (A) and grab sampling (B) at the four study sites during the three sampling campaigns 
A

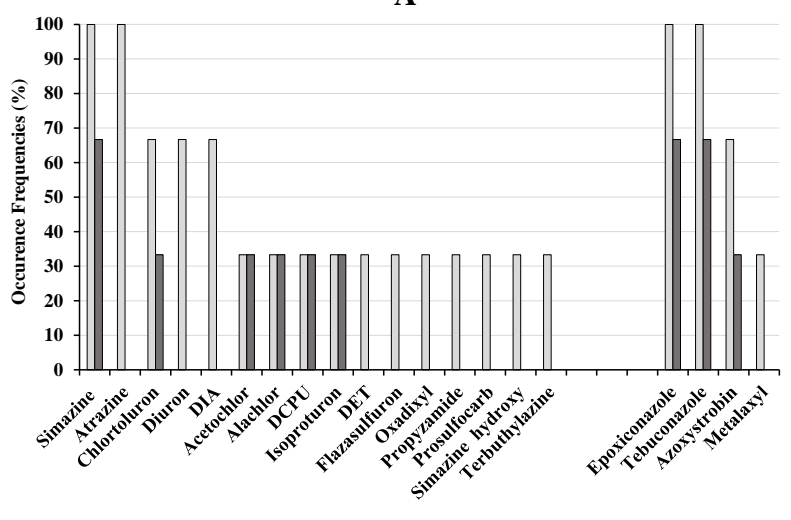

C

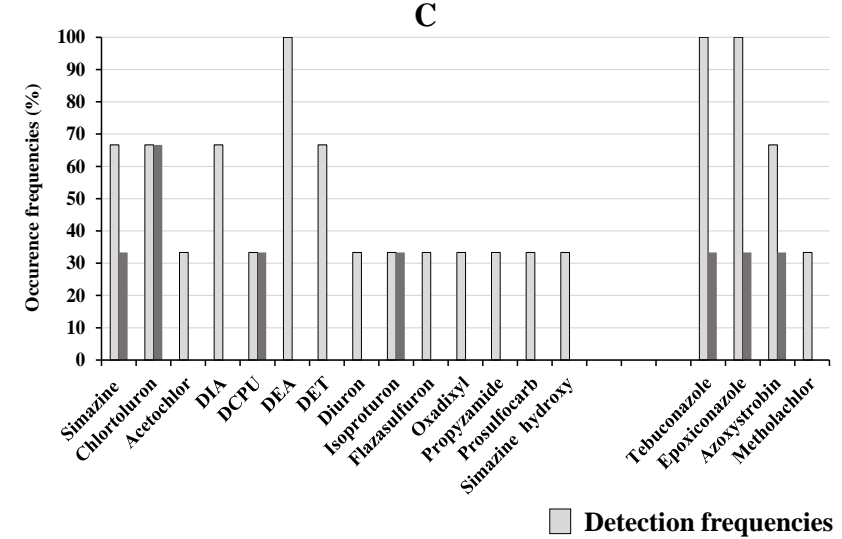

B

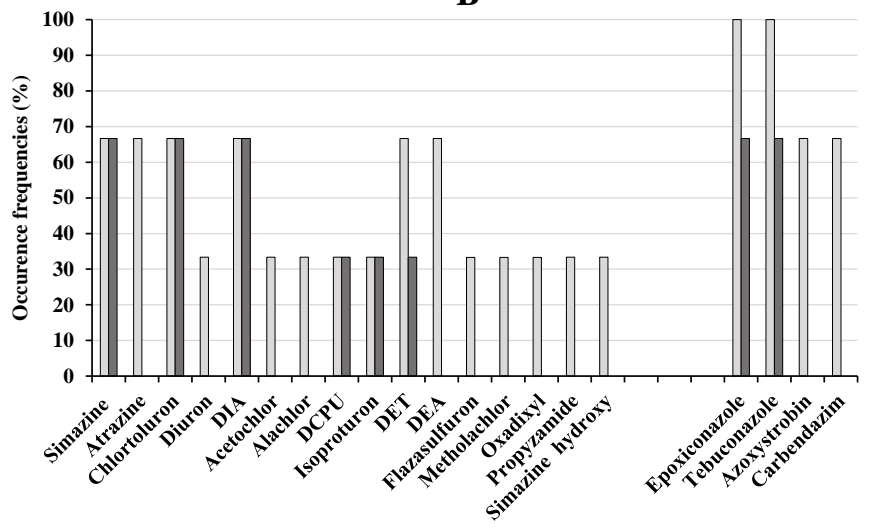

D

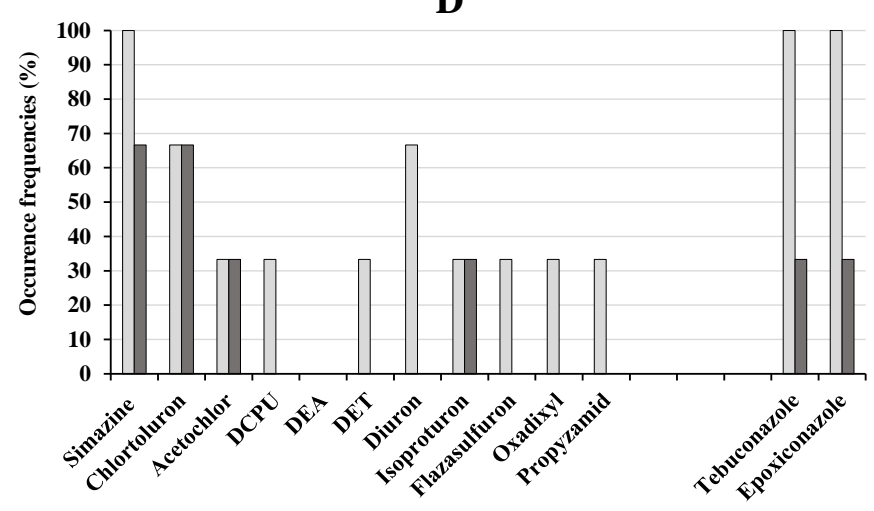

$\square$ Quantification frequencies

Fig. 3 Detection and quantification frequencies of targeted herbicides and fungicides in the lagoon (A), Chegui oued (B), Garaa oued (C) and Tinja oued (D), the sites sampled by passive sampling during the three sampling campaigns in 2015 and 2016 


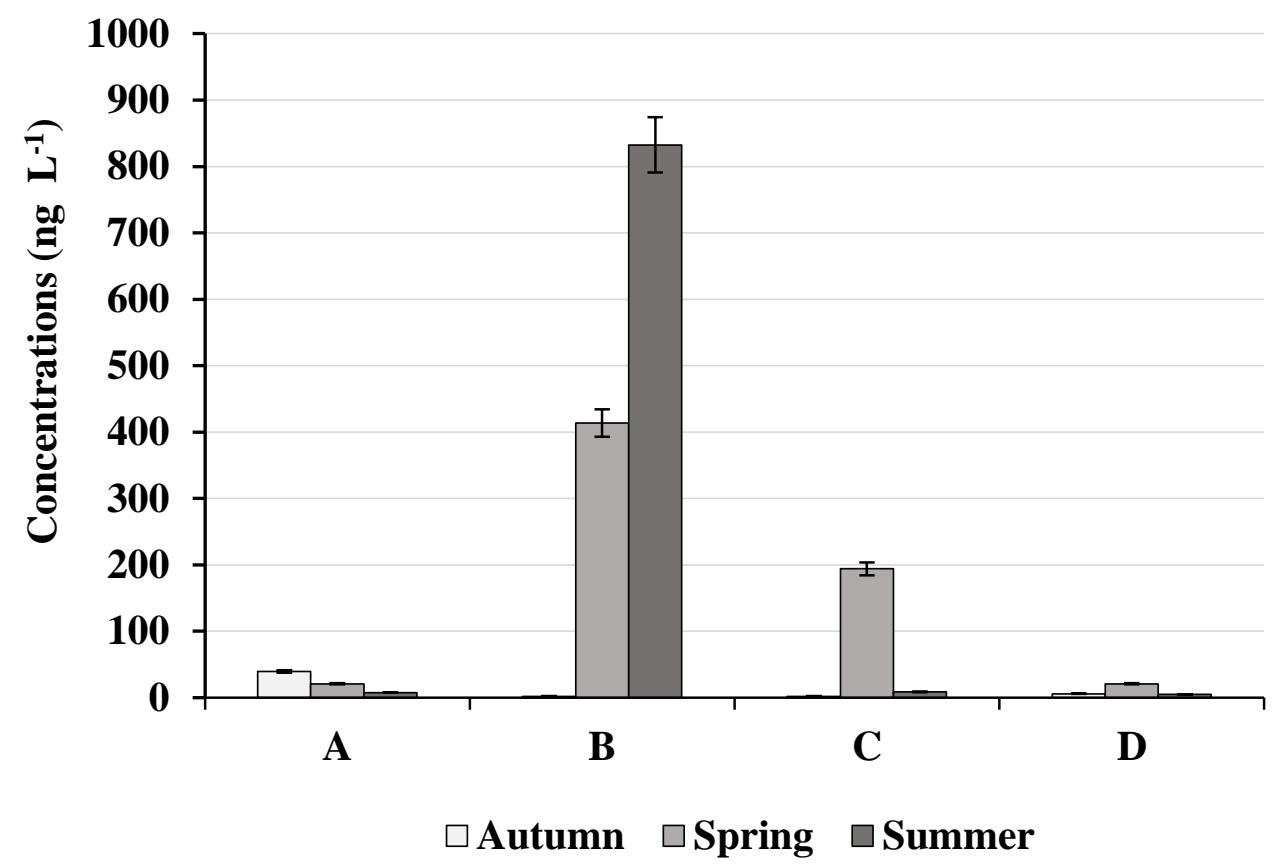

Fig. 4 Total pesticide concentrations $\left(n g \mathrm{~L}^{-1}\right)$ in the water obtained by passive sampling as a function of the sampling site (lagoon (A), Chegui oued (B), Garaa oued (C) and Tinja oued (D)) and season 
A
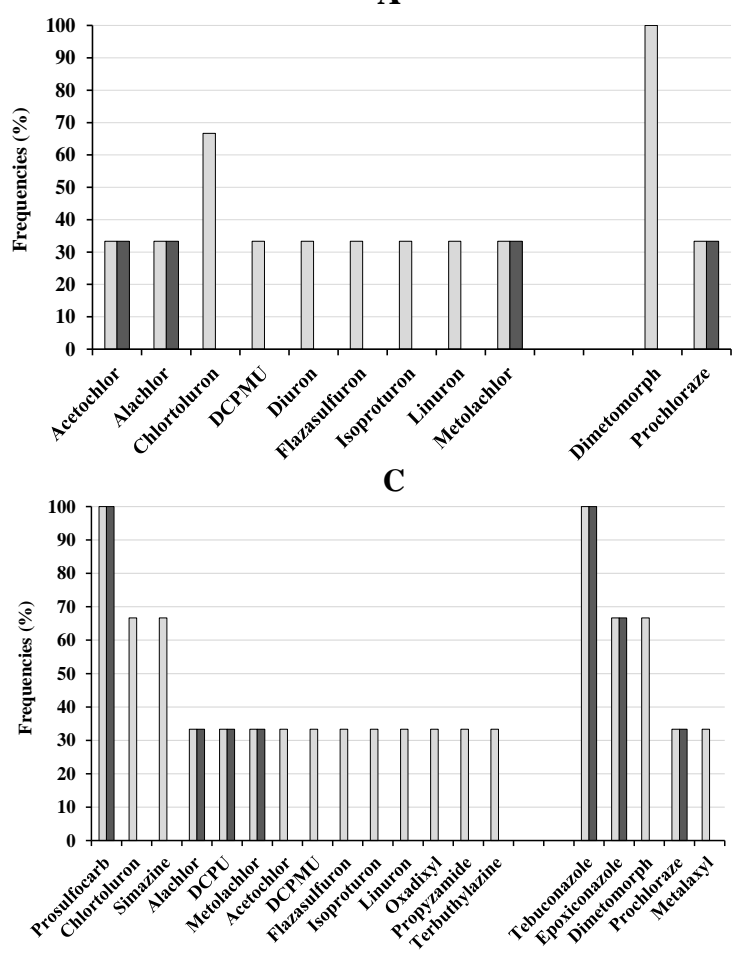

Detection frequencies
B
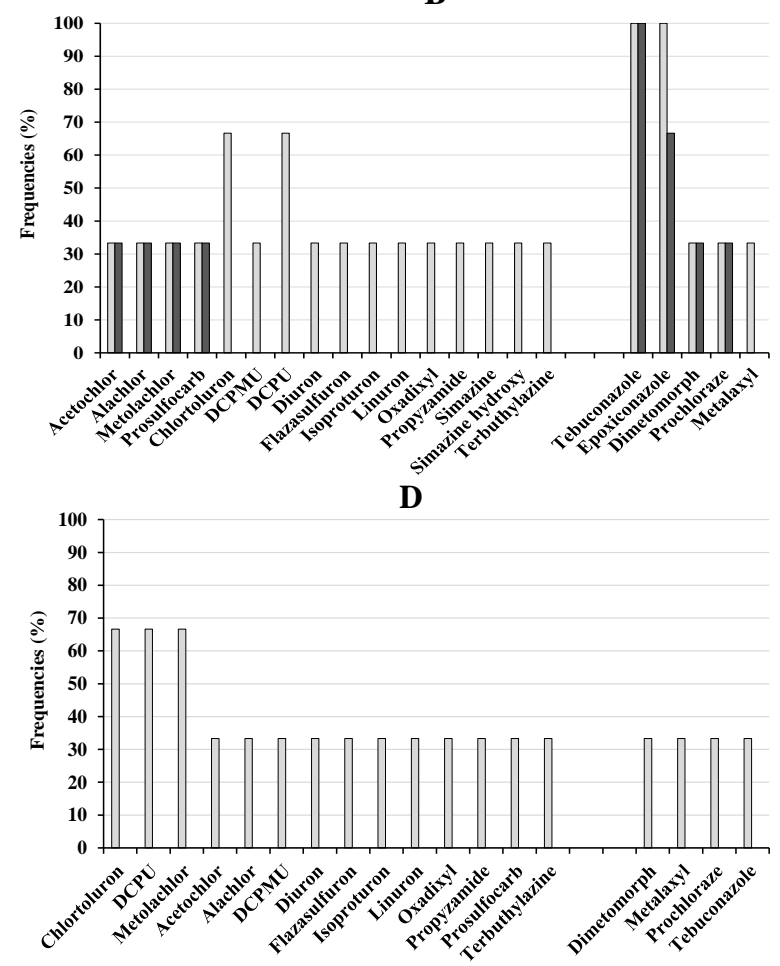

Quantification frequencies

Fig. 5 Detection and quantification frequencies of targeted herbicides and fungicides in the sediments at sampling sites in the lagoon (A), Chegui oued (B), Garaa oued (C) and Tinja oued (D) during the three sampling campaigns in 2015 and 2016 

Table 1 Limits of detection (LOD) and quantification (LOQ) obtained by HPLC-MS/MS, and LOQ calculated for POCIS (Poulier et al., 2014), water, sediment and laboratory sampling rates of the 32 targeted compounds

\begin{tabular}{|c|c|c|c|c|c|c|c|c|c|}
\hline $\begin{array}{l}\text { Pesticide active } \\
\text { substance }\end{array}$ & Chemical class & $\begin{array}{c}\text { Analytical LOD } \\
\left(\mu \mathrm{g} \mathrm{L^{-1 }}\right)\end{array}$ & $\begin{array}{c}\text { Analytical LOQ } \\
\left(\mu \mathrm{g} \mathrm{L} \mathbf{L}^{-1}\right)\end{array}$ & $\begin{array}{c}\text { LOQ } \\
\text { POCIS (ng } \\
\left.\text { L }^{-1}\right)\end{array}$ & $\begin{array}{l}\text { LOQ water } \\
(\text { ng L L }\end{array}$ & $\begin{array}{c}\text { LQ } \\
\text { sediment ng } \\
\mathbf{g}^{-1}\end{array}$ & $\begin{array}{c}\text { Water } \\
\text { recovery } \\
\text { rate }(\%)\end{array}$ & $\begin{array}{l}\text { Sampling } \\
\text { rates }\left(\mathbf{L ~ d}^{-1}\right)\end{array}$ & $\begin{array}{c}\text { Rs references } \\
\quad\left(\mathbf{L ~ d} \mathbf{d}^{-1}\right)\end{array}$ \\
\hline \multicolumn{10}{|c|}{ Herbicides } \\
\hline Acetochlor & Chloracetanilide & 2.2 & 7.5 & 1.6 & 22.5 & 2.2 & 83 & 0.223 & $\begin{array}{c}\text { (Ibrahim et al. } \\
\text { 2013a) }\end{array}$ \\
\hline Alachlor & Chloroacetamide & 1.1 & 3.8 & 0.7 & 11.4 & 1.1 & 76 & 0.256 & $\begin{array}{l}\text { (Ibrahim et al. } \\
\text { 2013a) }\end{array}$ \\
\hline Atrazine & Triazine & 0.4 & 1.5 & 0.3 & 4.4 & 0.4 & 88 & 0.254 & $\begin{array}{c}\text { (Ibrahim et al. } \\
\text { 2013a) }\end{array}$ \\
\hline Chlortoluron & Urea & 0.7 & 2.3 & 0.4 & 6.8 & 0.7 & 43 & 0.252 & $\begin{array}{c}\text { (Ibrahim et al. } \\
\text { 2013a) }\end{array}$ \\
\hline DCPMU** & Urea & 1.0 & 3.5 & 0.6 & 10.4 & 1.0 & 19 & 0.285 & $\begin{array}{c}\text { (Ibrahim et al. } \\
\text { 2013a) }\end{array}$ \\
\hline DCPU** & Urea & 1.2 & 4.0 & 0.6 & 12.0 & 1.2 & 8 & 0.333 & $\begin{array}{c}\text { (Ibrahim et al. } \\
\text { 2013b) }\end{array}$ \\
\hline DEA** & Triazine & 1.1 & 3.7 & 1.3 & 11.0 & 1.1 & 92 & 0.133 & $\begin{array}{c}\text { (Ibrahim et al. } \\
\text { 2013b) }\end{array}$ \\
\hline $\mathrm{DET}^{* *}$ & Triazine & 0.5 & 1.7 & 0.3 & 5.0 & 0.5 & 69 & 0.254 & $\begin{array}{c}\text { (Ibrahim et al. } \\
2013 b \text { ) }\end{array}$ \\
\hline DIA** & Triazine & 1.0 & 3.4 & 2.4 & 10.1 & 1.0 & 69 & 0.068 & $\begin{array}{c}\text { (Ibrahim et al. } \\
2013 b \text { ) }\end{array}$ \\
\hline Diuron & Phenylurea & 0.7 & 2.3 & 0.4 & 6.9 & 0.7 & 68 & 0.257 & $\begin{array}{c}\text { (Ibrahim et al. } \\
\text { 2013a) }\end{array}$ \\
\hline Flazasulfuron & Sulfonylurea & 0.7 & 2.2 & - & 6.6 & 0.7 & 0 & Unavalaible & - \\
\hline Isoproturon & Urea & 0.9 & 2.9 & 0.6 & 8.7 & 0.9 & 48 & 0.237 & $\begin{array}{c}\text { (Ibrahim et al. } \\
\text { 2013a) }\end{array}$ \\
\hline Linuron & Urea & 0.9 & 2.8 & 1.0 & 8.5 & 0.9 & 90 & 0.141 & $\begin{array}{c}\text { (Ibrahim et al. } \\
\text { 2013a) }\end{array}$ \\
\hline Metolachlor & Chloracetanilide & 0.4 & 1.3 & 0.2 & 4.0 & 0.4 & 69 & 0.268 & $\begin{array}{c}\text { (Ibrahim et al. } \\
2013 b \text { ) }\end{array}$ \\
\hline Oxadixyl & Phenylamide & 1.1 & 3.6 & 0.7 & 10.8 & 1.1 & 55 & 0.263 & $\begin{array}{c}\text { (Ibrahim et al. } \\
\text { 2013a) }\end{array}$ \\
\hline Propyzamide & Benzamide & 0.8 & 2.6 & 0.6 & 7.8 & 0.8 & 90 & 0.195 & $\begin{array}{c}\text { (Ibrahim et al. } \\
\text { 2013a) }\end{array}$ \\
\hline
\end{tabular}




\begin{tabular}{|c|c|c|c|c|c|c|c|c|c|}
\hline Prosulfocarb* & Thiocarbamate & 0.5 & 1.6 & 1.0 & 4.7 & 0.5 & 67 & 0.071 & $\begin{array}{c}\text { (Ibrahim et al. } \\
\text { 2013a) }\end{array}$ \\
\hline Simazine* & Triazine & 0.1 & 0.4 & 0.1 & 1.2 & 0.1 & 101 & 0.218 & $\begin{array}{l}\text { (Ibrahim et al. } \\
\text { 2013a) }\end{array}$ \\
\hline $\begin{array}{l}\text { Simazine } \\
\text { Hydroxy }\end{array}$ & Triazine & 0.7 & 2.3 & - & 6.9 & 0.7 & 0 & Unavalaible & - \\
\hline Terbuthylazine & Triazine & 0.3 & 1.1 & 0.3 & 3.3 & 0.3 & 87 & 0.163 & $\begin{array}{c}\text { (Ibrahim et al. } \\
\text { 2013a) }\end{array}$ \\
\hline $\begin{array}{c}\text { Terbuthylazine } \\
\text { Hydroxy }\end{array}$ & Triazine & 0.7 & 2.5 & - & 7.4 & 0.7 & 0 & Unavalaible & - \\
\hline \multicolumn{10}{|c|}{ Fungicides } \\
\hline Azoxystrobin* & Strobilurin & 1.0 & 3.2 & 1.0 & 9.5 & 1.0 & 66 & 0.154 & $\begin{array}{c}\text { (Ibrahim et al. } \\
\text { 2013a) }\end{array}$ \\
\hline Carbendazim* & Bendimidazole & 0.5 & 1.6 & 0.3 & 4.8 & 0.5 & 21 & 0.304 & (Poulier et al. 2015) \\
\hline Dimetomorph & Morpholine & 0.6 & 1.9 & 0.2 & 5.8 & 0.6 & 66 & 0.395 & (Poulier et al. 2015) \\
\hline Epoxiconazole* & Triazole & 0.7 & 2.3 & 0.4 & 6.9 & 0.7 & 73 & 0.280 & (Ahrens et al. 2015) \\
\hline Metalaxyl & Phenylamide & 0.8 & 2.7 & 0.5 & 8.0 & 0.8 & 55 & 0.264 & $\begin{array}{l}\text { (Ibrahim et al. } \\
\text { 2013a) }\end{array}$ \\
\hline Penconazole & Triazole & 1.0 & 3.4 & 0.6 & 10.2 & 1.0 & 99 & 0.279 & $\begin{array}{c}\text { (Ibrahim et al. } \\
\text { 2013a) }\end{array}$ \\
\hline Prochloraz* & Azole & 0.200 & 0.7 & 0.4 & 2.0 & 0.2 & 60 & 0.080 & (Desgranges 2015) \\
\hline Pyrimethanil & Anilinopyrimidine & 1.1 & 3.6 & 0.7 & 10.9 & 1.1 & 89 & 0.231 & $\begin{array}{l}\text { (Ibrahim et al. } \\
\text { 2013a) }\end{array}$ \\
\hline Tebuconazole* & Triazole & 0.7 & 2.2 & 0.4 & 6.5 & 0.7 & 71 & 0.240 & $\begin{array}{c}\text { (Greenwood et al. } \\
\text { 2007) }\end{array}$ \\
\hline Tetraconazole & Triazole & 0.7 & 2.2 & - & 6.6 & 0.7 & 92 & Unavalaible & - \\
\hline \multicolumn{10}{|c|}{ Insecticides } \\
\hline Imidacloprid & Neonicotinoide & 1.7 & 5.6 & 0.9 & 16.7 & 1.7 & 0.8 & 0.290 & (Poulier et al. 2015) \\
\hline
\end{tabular}

*Pesticides inventoried in the survey

** Degradation products: DCPMU: 1-(3,4-dichlorophenyl)-3-methylurea / DCPU: 3,4-dichlorophenyl urea / DEA: desethylatrazine / DET: desethyl terbuthylazine / DIA : deisopropylatrazine 
Table 2 Inventoried active ingredients in the agricultural regions of the Bizerte lagoon watershed surveyed (south of Bizerte, Tinja, and

\section{Menzel Bourguiba)}

\begin{tabular}{|c|c|c|c|c|}
\hline Active ingredients & Chemical classes & Pesticides & $\begin{array}{c}\text { Estimated } \\
\text { doses }\left(\mathrm{g} \mathrm{ha}^{-1}\right)\end{array}$ & Crops \\
\hline \multicolumn{5}{|c|}{ Fungicides } \\
\hline Azoxystrobin** & Strobilurins & Fungicide & 200 & Wheat. pulses \\
\hline Difenoconazole & Triazoles & Fungicide & 125 & Vine \\
\hline Mancozeb & Carbamates & Fungicide & 40 & Vine \\
\hline Maneb & Carbamates & Fungicide & 10 & Vine \\
\hline Zineb* & Carbamates & Fungicide & 10 & Vine \\
\hline Boscalid & Carboxamides & Fungicide & 7.50 & Vine \\
\hline Chlorothalonil** & Organochlorines (chloronitriles) & Fungicide & 5.50 & Pulses \\
\hline Prochloraz ${ }^{* *}$ & Imidazoles & Fungicide & 2.25 & Wheat . barley \\
\hline Tebuconazole** & Triazoles & Fungicide & 1.25 & wheat. barley. oat. \\
\hline Spiroxamine & Spirocetalamines & Fungicide & 1.12 & Vine \\
\hline Flusilazole $* *$ & Triazoles & Fungicide & 1 & Barley \\
\hline Thiophanate-methyl & Benzimidazoles & Fungicide & 0.78 & Vine \\
\hline Flutriafol** & Triazoles & Fungicide & 0.6 & Barley \\
\hline Propiconazole ${ }^{* *}$ & Triazoles & Fungicide & 0.63 & Barley \\
\hline Carbendazim** & Benzimidazoles & Fungicide & 0.50 & Cereals. wheat \\
\hline Prothioconazole ${ }^{* *}$ & Triazolinthiones & Fungicide & 0.50 & Cereals \\
\hline Epoxiconazole $* *$ & Triazoles & Fungicide & 0.47 & Wheat . barley \\
\hline Kresoxim-methyl & Strobilurins & Fungicide & 0.44 & Vine \\
\hline Cyproconazole & Triazoles & Fungicide & 0.20 & Oat \\
\hline Metconazol* & Triazoles & Fungicide & 0.01 & Wheat . barley \\
\hline \multicolumn{5}{|c|}{ Insecticides } \\
\hline Bifenthrin & Pyrethroides & Insecticide & 80 & Vine . fruit trees \\
\hline Deltamethrin & Pyrethroides & Insecticide & 62.5 & Vine. fruit trees. cereals \\
\hline \multicolumn{5}{|c|}{ Herbicides } \\
\hline Glyphosate** & Amino- phosphonates & Herbicide & 21.60 & All crops \\
\hline Simazine $* *$ & Triazines & Herbicide & 3.75 & Pulses \\
\hline Bentazone $* *$ & Diazines & Herbicide & 3 & Cereals . pulses \\
\hline Prosulfocarb** & Thiocarabamates & Herbicide & 1 & Wheat \\
\hline $2.4 \mathrm{D} * *$ & Esters & Herbicide & 0.90 & Wheat. barley . oat \\
\hline Clethodim & Cyclohexanes diones & Herbicide & 0.60 & Pulses \\
\hline Fenoxaprop-p-ethyl* & Aryloxyphe-noxy-propionates (FOPS) & Herbicide & 0.28 & Cereals \\
\hline Mefenpyr-diethyl & Pyrazoles & Herbicide & 0.23 & Cereals \\
\hline
\end{tabular}




$\begin{array}{ccccc}\text { Clodinafop-propagyl } & \text { Aryloxy-phenoxy-propionates (FOPS) } & \text { Herbicide } & 0.14 & \text { Wheat } \\ \text { Pinoxaden* } & \text { Phenylpyrazolines } & \text { Herbicide } & 0.14 & \text { Wheat } \\ \text { Pyroxulam* } & \text { Triazolopyrimidines } & \text { Herbicide } & 0.12 & \text { Cereals } \\ \text { Mesosulfuron-methyl } & \text { Sulfonylurea } & \text { Herbicide } & 0.08 & \text { Cereals } \\ \text { Tribenuron-Méthyl } & \text { Sulfonylurea } & \text { Herbicide } & 0.05 & \text { Cereals } \\ \text { Aminopyralid } & \text { Triazolopyrimidines } & \text { Herbicide } & 0.05 & \text { Wheat. oat! } \\ \text { Cloquintocet-mexyl } & \text { Phenylpyrazolines } & \text { Herbicide } & 0.03 & \text { Barley } \\ \text { Florasulam } & \text { Thiocarabamates } & \text { Herbicide } & 0.02 & \text { Cereals } \\ \text { Iodosulfuron } & \text { Sulfonylurea } & \text { Herbicide } & 0.02 & \text { Cereals } \\ \text { Trifluralin } & \text { Dinitroanilines } & \text { Herbicide } & 0.01 & \text { Pulses } \\ * \text { Active ingredients } \text { not approved in Tunisia (Mezghani et al. 2016) }\end{array}$

**Active ingredients from the list of 15 selected pesticides 
Table 3 Pesticides quantified by POCIS as a function of the site and the season (mean concentrations $\mathbf{n g ~ L ~}^{-1}$; $\mathbf{n}=\mathbf{3}$ injections)

\begin{tabular}{|c|c|c|c|c|c|c|c|c|c|c|c|c|c|c|c|c|c|c|c|c|c|c|c|c|c|}
\hline \multirow{3}{*}{ Pesticides } & \multirow{3}{*}{ Survey } & \multicolumn{6}{|c|}{$\overline{\text { Lagoon }(\mathrm{A})}$} & \multicolumn{6}{|c|}{ Chegui oued (B) } & \multicolumn{6}{|c|}{ Garaa oued (C) } & \multicolumn{6}{|c|}{ Tinja oued (D) } \\
\hline & & \multicolumn{2}{|c|}{$\begin{array}{l}\text { Autumn } \\
2015\end{array}$} & \multicolumn{2}{|c|}{ Spring 2016} & \multicolumn{2}{|c|}{ Summer 2016} & \multicolumn{2}{|c|}{$\begin{array}{l}\text { Autumn } \\
2015\end{array}$} & \multicolumn{2}{|c|}{ Spring 2016} & \multicolumn{2}{|c|}{ Summer 2016} & \multicolumn{2}{|c|}{$\begin{array}{l}\text { Autumn } \\
2015\end{array}$} & \multicolumn{2}{|c|}{ Spring 2016} & \multicolumn{2}{|c|}{ Summer 2016} & \multicolumn{2}{|c|}{$\begin{array}{l}\text { Autumn } \\
2015\end{array}$} & \multicolumn{2}{|c|}{ Spring 2016} & Summe & 2016 \\
\hline & & Mean & SD & Mean & SD & Mean & SD & Mean & SD & Mean & SD & Mean & SD & Mean & SD & Mean & SD & Mean & SD & Mean & SD & Mean & SD & Mean & SD \\
\hline & & & & & & & & & & & & bicides & & & & & & & & & & & & & \\
\hline Acetochlor & nd & 13.5 & 1.2 & $<\mathrm{LOD}$ & & $\angle \mathrm{LOD}$ & & $<\mathrm{LOQ}$ & & $\angle \mathrm{LOD}$ & & $<\mathrm{LOD}$ & & $\angle \mathrm{LOD}$ & & $\angle \mathrm{LOQ}$ & & $\angle \mathrm{LOD}$ & & $\angle \mathrm{LOD}$ & & 5.0 & 1.3 & $\angle \mathrm{LOD}$ & \\
\hline Alachlor & nd & 2.7 & 0.3 & $<\mathrm{LOD}$ & & $<\mathrm{LOD}$ & & $<\mathrm{LOQ}$ & & $<\mathrm{LOD}$ & & $<\mathrm{LOD}$ & & $<\mathrm{LOD}$ & & $\angle \mathrm{LOD}$ & & $<\mathrm{LOD}$ & & $<\mathrm{LOD}$ & & $\begin{array}{l}\mathrm{LOD} \\
\end{array}$ & & $<$ LOD & \\
\hline Atrazine & nd & $<\mathrm{LOQ}$ & & $<\mathrm{LOQ}$ & & $<\mathrm{LOQ}$ & & $<\mathrm{LOQ}$ & & $<\mathrm{LOQ}$ & & $<\mathrm{LOD}$ & & $\angle \mathrm{LOD}$ & & $\angle \mathrm{LOD}$ & & $\angle \mathrm{LOD}$ & & $<\mathrm{LOD}$ & & $\angle \mathrm{LOD}$ & & $\angle \mathrm{LOD}$ & \\
\hline Chlortoluron** & nd & $<\mathrm{LOQ}$ & & $<\mathrm{LOD}$ & & 3.6 & 0.1 & $<\mathrm{LOD}$ & & 2.3 & 1.6 & 3.1 & 0.1 & $<\mathrm{LOD}$ & & 17.0 & 5.3 & 4.1 & 0.3 & $<\mathrm{LOD}$ & & 3.0 & 1.2 & 2.3 & 0.2 \\
\hline DCPMU* & nd & $\angle \mathrm{LOD}$ & & $<\mathrm{LOD}$ & & $<\mathrm{LOD}$ & & $<\mathrm{LOD}$ & & $<\mathrm{LOD}$ & & $<\mathrm{LOD}$ & & $<\mathrm{LOD}$ & & $\angle \mathrm{LOD}$ & & $<\mathrm{LOD}$ & & $<\mathrm{LOD}$ & & $\angle \mathrm{LOD}$ & & $\angle \mathrm{LOD}$ & \\
\hline DCPU* & nd & 1.8 & 0.1 & $<\mathrm{LOD}$ & & $<\mathrm{LOD}$ & & $<\mathrm{LOD}$ & & 1.0 & 0.9 & $<\mathrm{LOD}$ & & $<\mathrm{LOD}$ & & 0.9 & 0.3 & $<\mathrm{LOD}$ & & $<\mathrm{LOQ}$ & & $\begin{array}{l}\mathrm{LOD} \\
\end{array}$ & & $\begin{array}{l}\mathrm{LOD} \\
\end{array}$ & \\
\hline DEA* & nd & $<\mathrm{LOD}$ & & $<\mathrm{LOD}$ & & $\angle \mathrm{LOD}$ & & $<\mathrm{LOQ}$ & & $\angle \mathrm{LOD}$ & & $<\mathrm{LOQ}$ & & $\angle \mathrm{LOQ}$ & & $\angle \mathrm{LOQ}$ & & $<\mathrm{LOQ}$ & & $\angle \mathrm{LOD}$ & & $\angle \mathrm{LOD}$ & & $\angle \mathrm{LOD}$ & \\
\hline DET* & nd & $<\mathrm{LOD}$ & & $<\mathrm{LOD}$ & & $<\mathrm{LOQ}$ & & $<\mathrm{LOD}$ & & $<\mathrm{LOQ}$ & & 5.0 & 0.9 & $<\mathrm{LOQ}$ & & $\angle \mathrm{LOD}$ & & $<\mathrm{LOQ}$ & & $<\mathrm{LOD}$ & & $\begin{array}{l}\mathrm{LOD} \\
\end{array}$ & & $\begin{array}{l}\mathrm{LOQ} \\
\end{array}$ & \\
\hline DIA* & nd & $<\mathrm{LOQ}$ & & $<\mathrm{LOD}$ & & $\angle \mathrm{LOQ}$ & & $<\mathrm{LOD}$ & & 93.3 & 6.1 & 192.0 & 4.6 & $<\mathrm{LOD}$ & & $<\mathrm{LOQ}$ & & $<\mathrm{LOQ}$ & & $<\mathrm{LOD}$ & & $\angle \mathrm{LOD}$ & & $<\mathrm{LOD}$ & \\
\hline Diuron & nd & $<\mathrm{LOQ}$ & & $<\mathrm{LOD}$ & & $<\mathrm{LOD}$ & & $<\mathrm{LOD}$ & & $<\mathrm{LOD}$ & & $<\mathrm{LOQ}$ & & $<\mathrm{LOD}$ & & $<\mathrm{LOD}$ & & $<\mathrm{LOQ}$ & & $<\mathrm{LOQ}$ & & $<$ LOD & & $<\mathrm{LOQ}$ & \\
\hline Flazasulfuron & nd & $<\mathrm{LOQ}$ & & $<\mathrm{LOD}$ & & $<\mathrm{LOD}$ & & $<\mathrm{LOD}$ & & $<\mathrm{LOQ}$ & & $<\mathrm{LOD}$ & & $<\mathrm{LOD}$ & & $<\mathrm{LOQ}$ & & $<\mathrm{LOD}$ & & $<\mathrm{LOD}$ & & $\angle \mathrm{LOQ}$ & & $\angle \mathrm{LOD}$ & \\
\hline Isoproturon & nd & $<\mathrm{LOD}$ & & $<\mathrm{LOD}$ & & 4.0 & 1.1 & $\angle \mathrm{LOD}$ & & $\angle \mathrm{LOD}$ & & 1.8 & 0.2 & $\angle \mathrm{LOD}$ & & $\angle \mathrm{LOD}$ & & 4.4 & 0.2 & $\angle \mathrm{LOD}$ & & $\angle \mathrm{LOD}$ & & 2.4 & 0.1 \\
\hline Linuron** & nd & $<\mathrm{LOD}$ & & $<\mathrm{LOD}$ & & $<\mathrm{LOD}$ & & $<\mathrm{LOD}$ & & $\angle \mathrm{LOD}$ & & $<\mathrm{LOD}$ & & $<\mathrm{LOD}$ & & $\angle \mathrm{LOD}$ & & $<\mathrm{LOD}$ & & $<\mathrm{LOD}$ & & $\begin{array}{l}\mathrm{LOD} \\
\end{array}$ & & $\angle \mathrm{LOD}$ & \\
\hline Metolachlor & nd & $<\mathrm{LOD}$ & & $<\mathrm{LOD}$ & & $\angle \mathrm{LOD}$ & & $<\mathrm{LOD}$ & & $<\mathrm{LOD}$ & & $<\mathrm{LOD}$ & & $\angle \mathrm{LOD}$ & & $\angle \mathrm{LOQ}$ & & $<\mathrm{LOD}$ & & $<\mathrm{LOD}$ & & $\angle \mathrm{LOD}$ & & $\angle \mathrm{LOD}$ & \\
\hline Oxadixyl & nd & $\angle \mathrm{LOD}$ & & $<\mathrm{LOQ}$ & & $\angle \mathrm{LOD}$ & & $<\mathrm{LOD}$ & & $<\mathrm{LOQ}$ & & $<\mathrm{LOD}$ & & $\angle \mathrm{LOD}$ & & $\angle \mathrm{LOQ}$ & & $<\mathrm{LOD}$ & & $<\mathrm{LOD}$ & & $\angle \mathrm{LOQ}$ & & $\angle \mathrm{LOD}$ & \\
\hline Propyzamide & nd & $<\mathrm{LOD}$ & & $<\mathrm{LOD}$ & & $\angle \mathrm{LOQ}$ & & $\angle \mathrm{LOD}$ & & $<\mathrm{LOQ}$ & & $<\mathrm{LOD}$ & & $\angle \mathrm{LOD}$ & & $\angle \mathrm{LOQ}$ & & $<\mathrm{LOD}$ & & $<\mathrm{LOD}$ & & $\angle \mathrm{LOQ}$ & & $\angle \mathrm{LOD}$ & \\
\hline Prosulfocarb** & $\mathrm{d}$ & $<\mathrm{LOD}$ & & $<\mathrm{LOQ}$ & & $\angle \mathrm{LOD}$ & & $\angle \mathrm{LOD}$ & & $<\mathrm{LOD}$ & & $<\mathrm{LOD}$ & & $\angle \mathrm{LOD}$ & & $\angle \mathrm{LOQ}$ & & $<\mathrm{LOD}$ & & $<\mathrm{LOD}$ & & $<\mathrm{LOD}$ & & $<\mathrm{LOD}$ & \\
\hline Simazine** & $\mathrm{d}$ & 9.0 & 0.8 & 4.5 & 2.1 & $<\mathrm{LOQ}$ & & $<\mathrm{LOD}$ & & 168.0 & 11.1 & 431.6 & 7.2 & $<\mathrm{LOD}$ & & 20.0 & 1.3 & $<\mathrm{LOQ}$ & & 5.7 & 1.2 & 10.0 & 0.2 & $<\mathrm{LOQ}$ & \\
\hline $\begin{array}{l}\text { Simazine } \\
\text { hydroxy** }\end{array}$ & nd & $<\mathrm{LOD}$ & & $<\mathrm{LOD}$ & & $<\mathrm{LOQ}$ & & $<\mathrm{LOD}$ & & $<$ LOD & & $<\mathrm{LOQ}$ & & $<\mathrm{LOD}$ & & $<$ LOD & & $<\mathrm{LOQ}$ & & $<\mathrm{LOD}$ & & $<\mathrm{LOD}$ & & $<$ LOD & \\
\hline Terbuthylazine** & nd & $<\mathrm{LOD}$ & & $<$ LOD & & $<\mathrm{LOQ}$ & & $<\mathrm{LOD}$ & & $<\mathrm{LOD}$ & & $<\mathrm{LOD}$ & & $<\mathrm{LOD}$ & & $<$ LOD & & $<\mathrm{LOD}$ & & $<\mathrm{LOD}$ & & $\angle \mathrm{LOD}$ & & $<$ LOD & \\
\hline $\begin{array}{c}\text { Terbuthylazine } \\
\text { hydroxy* }\end{array}$ & nd & $<\mathrm{LOD}$ & & $<\mathrm{LOD}$ & & $<\mathrm{LOD}$ & & $<\mathrm{LOD}$ & & $<\mathrm{LOD}$ & & $<\mathrm{LOD}$ & & $<\mathrm{LOD}$ & & $<$ LOD & & $<\mathrm{LOD}$ & & $<\mathrm{LOD}$ & & $<\mathrm{LOD}$ & & $<\mathrm{LOD}$ & \\
\hline & & & & & & & & & & & & gicides & & & & & & & & & & & & & \\
\hline Azoxystrobine** & $\mathrm{d}$ & $<\mathrm{LOD}$ & & 6.5 & 1.3 & $<\mathrm{LOQ}$ & & $<\mathrm{LOD}$ & & $<\mathrm{LOQ}$ & & $<\mathrm{LOQ}$ & & $<\mathrm{LOD}$ & & 8.0 & 0.1 & $<\mathrm{LOQ}$ & & $<\mathrm{LOD}$ & & $\begin{array}{l}\mathrm{LOD} \\
\end{array}$ & & $\begin{array}{l}\mathrm{LOD} \\
\end{array}$ & \\
\hline Carbendazim** & $\mathrm{d}$ & $<\mathrm{LOD}$ & & $<\mathrm{LOD}$ & & $\angle \mathrm{LOD}$ & & $<\mathrm{LOD}$ & & $<\mathrm{LOQ}$ & & $<\mathrm{LOQ}$ & & $<\mathrm{LOD}$ & & $\angle \mathrm{LOD}$ & & $\angle \mathrm{LOD}$ & & $<\mathrm{LOD}$ & & $\angle \mathrm{LOD}$ & & $\angle \mathrm{LOD}$ & \\
\hline Dimetomorph** & nd & $<\mathrm{LOD}$ & & $<\mathrm{LOD}$ & & $<\mathrm{LOD}$ & & $<\mathrm{LOD}$ & & $<\mathrm{LOD}$ & & $<\mathrm{LOD}$ & & $<\mathrm{LOD}$ & & $<$ LOD & & $<\mathrm{LOD}$ & & $<\mathrm{LOD}$ & & $<$ LOD & & $<$ LOD & \\
\hline Epoxiconazole** & nd & 8.4 & 0.9 & 5.8 & 3.0 & $<\mathrm{LOQ}$ & & $<\mathrm{LOQ}$ & & 7.2 & 1.8 & 8.5 & 0.9 & $<\mathrm{LOQ}$ & & 46.0 & 2.0 & $<\mathrm{LOQ}$ & & $<\mathrm{LOQ}$ & & 2.0 & 0.9 & $\begin{array}{l}\mathrm{LOQ} \\
\end{array}$ & \\
\hline Metalaxyl** & nd & $<\mathrm{LOD}$ & & $<\mathrm{LOD}$ & & $<\mathrm{LOQ}$ & & $<\mathrm{LOD}$ & & $<\mathrm{LOD}$ & & $<\mathrm{LOD}$ & & $<\mathrm{LOD}$ & & $\angle \mathrm{LOD}$ & & $<\mathrm{LOD}$ & & $<\mathrm{LOD}$ & & $\angle \mathrm{LOD}$ & & $<\mathrm{LOD}$ & \\
\hline Penconazole** & nd & $<\mathrm{LOD}$ & & $<\mathrm{LOD}$ & & $<\mathrm{LOD}$ & & $<\mathrm{LOD}$ & & $<\mathrm{LOD}$ & & $<\mathrm{LOD}$ & & $<\mathrm{LOD}$ & & $<\mathrm{LOD}$ & & $<\mathrm{LOD}$ & & $<\mathrm{LOD}$ & & $<$ LOD & & $<\mathrm{LOD}$ & \\
\hline Prochloraze** & $\mathrm{d}$ & $<\mathrm{LOD}$ & & $<\mathrm{LOD}$ & & $\angle \mathrm{LOD}$ & & $<\mathrm{LOD}$ & & $<\mathrm{LOD}$ & & $<\mathrm{LOD}$ & & $\angle \mathrm{LOD}$ & & $\angle \mathrm{LOD}$ & & $<\mathrm{LOD}$ & & $\angle \mathrm{LOD}$ & & $\angle \mathrm{LOD}$ & & $\angle \mathrm{LOD}$ & \\
\hline Pyrimethanil** & nd & $<\mathrm{LOD}$ & & $<\mathrm{LOD}$ & & $\angle \mathrm{LOD}$ & & $<\mathrm{LOD}$ & & $\angle \mathrm{LOD}$ & & $<\mathrm{LOD}$ & & $\angle \mathrm{LOD}$ & & $\angle \mathrm{LOD}$ & & $\angle \mathrm{LOD}$ & & $\angle \mathrm{LOD}$ & & $\angle \mathrm{LOD}$ & & $\angle \mathrm{LOD}$ & \\
\hline Tebuconazole** & $\mathrm{d}$ & 3.9 & 0.9 & 4.0 & 0.3 & $<\mathrm{LOQ}$ & & $<\mathrm{LOQ}$ & & 142.0 & 9.0 & 190.5 & 11.4 & $<\mathrm{LOQ}$ & & 102.2 & 3.2 & $<\mathrm{LOQ}$ & & $<\mathrm{LOQ}$ & & 0.8 & 0.2 & $<\mathrm{LOQ}$ & \\
\hline Tetraconazole & nd & $<\mathrm{LOD}$ & & $<$ LOD & & $\angle \mathrm{LOD}$ & & $<\mathrm{LOD}$ & & $<\mathrm{LOD}$ & & $<\mathrm{LOD}$ & & $<\mathrm{LOD}$ & & $<\mathrm{LOD}$ & & $<\mathrm{LOD}$ & & $<\mathrm{LOD}$ & & $\angle \mathrm{LOD}$ & & $<\mathrm{LOD}$ & \\
\hline & & & & & & & & & & & & cticides & & & & & & & & & & & & & \\
\hline Imidacloprid** & $\mathrm{d}$ & $\angle \mathrm{LOD}$ & & $\angle \mathrm{LOD}$ & & $\angle \mathrm{LOD}$ & & $\angle \mathrm{LOD}$ & & $\angle \mathrm{LOD}$ & & $\angle \mathrm{LOD}$ & & $\angle \mathrm{LOD}$ & & $\angle \mathrm{LOD}$ & & $\angle \mathrm{LOD}$ & & $\angle \mathrm{LOD}$ & & $\angle \mathrm{LOD}$ & & $\angle \mathrm{LOD}$ & \\
\hline $\begin{array}{c}\text { Total } \\
\text { concentrations }\end{array}$ & & 39.3 & & 20.8 & & 7.6 & & $<\mathrm{LOD}$ & & 413.8 & & 832.5 & & $<\mathrm{LOD}$ & & 194.1 & & 8.5 & & 5.7 & & 20.8 & & 9.4 & \\
\hline
\end{tabular}

$d$ : determined in the survey; $n d:$ not determined in the survey; < LOD: concentration below the analytical detection limit; < LOQ: concentration below the analytical quantification; *: Degradation products; **: pesticides approved in Tunisia 
Table 4 Pesticides quantified by grab sampling as a function of the site and the season (mean concentrations $n \mathrm{~L}^{-1}$; $\mathbf{n = 3}$ injections)

\begin{tabular}{|c|c|c|c|c|c|c|c|c|c|c|c|c|c|c|c|c|c|c|c|c|c|c|c|c|c|}
\hline \multirow{3}{*}{ Pesticides } & \multirow{3}{*}{ Survey } & \multicolumn{6}{|c|}{ Lagoon (A) } & \multicolumn{6}{|c|}{ Chegui oued (B) } & \multicolumn{6}{|c|}{ Garaa oued (C) } & \multicolumn{6}{|c|}{ Tinja oued (D) } \\
\hline & & \multicolumn{2}{|c|}{ Autumn 2015} & \multicolumn{2}{|c|}{ Spring 2016} & \multicolumn{2}{|c|}{ Summer 2016} & \multicolumn{2}{|c|}{ Autumn 2015} & \multicolumn{2}{|c|}{ Spring 2016} & \multicolumn{2}{|c|}{ Summer 2016} & \multicolumn{2}{|c|}{$\begin{array}{c}\text { Autumn } \\
2015\end{array}$} & \multicolumn{2}{|c|}{ Spring 2016} & \multicolumn{2}{|c|}{ Summer 2016} & \multicolumn{2}{|c|}{ Autumn 2015} & \multicolumn{2}{|c|}{ Spring 2016} & Summe & 2016 \\
\hline & & Mean & SD & Mean & SD & Mean & SD & Mean & SD & Mean & SD & Mean & SD & Mean & SD & Mean & SD & Mean & SD & Mean & SD & Mean & SD & Mean & SD \\
\hline & & & & & & & & & & & Ierbici & & & & & & & & & & & & & & \\
\hline Acetochlor & nd & $<\mathrm{LOD}$ & & $\angle \mathrm{LOD}$ & & $\angle \mathrm{LOD}$ & & $\angle \mathrm{LOD}$ & & $<\mathrm{LOD}$ & & $\angle \mathrm{LOD}$ & & $<\mathrm{LOD}$ & & $\angle \mathrm{LOD}$ & & $<$ LOD & & $\angle \mathrm{LOD}$ & & $\angle \mathrm{LOD}$ & & $\angle \mathrm{LOD}$ & \\
\hline Alachlor & nd & $<\mathrm{LOD}$ & & $\angle \mathrm{LOD}$ & & $<\mathrm{LOD}$ & & $\angle \mathrm{LOD}$ & & $<\mathrm{LOD}$ & & $<\mathrm{LOD}$ & & $<\mathrm{LOD}$ & & $\angle$ LOD & & $<$ LOD & & $\angle \mathrm{LOD}$ & & $\angle$ LOD & & $\begin{array}{l}\text { LOD } \\
\end{array}$ & \\
\hline Atrazine & nd & $<\mathrm{LOD}$ & & $\angle \mathrm{LOD}$ & & $<\mathrm{LOD}$ & & $\angle \mathrm{LOD}$ & & $<\mathrm{LOD}$ & & $<\mathrm{LOD}$ & & $<\mathrm{LOD}$ & & $\angle \mathrm{LOD}$ & & $\angle \mathrm{LOD}$ & & $\angle \mathrm{LOD}$ & & $\angle \mathrm{LOD}$ & & $\angle \mathrm{LOD}$ & \\
\hline Chlortoluron** & nd & $<\mathrm{LOD}$ & & $<$ LOD & & 15.1 & 0.5 & $<\mathrm{LOQ}$ & & $<\mathrm{LOQ}$ & & 16.4 & 1.1 & $<\mathrm{LOD}$ & & 40.0 & 12.3 & 24.4 & 0.6 & $<\mathrm{LOD}$ & & 15.0 & 11.7 & 15.4 & 0.5 \\
\hline DCPMU* & nd & $<$ LOD & & $<$ LOD & & $<\mathrm{LOD}$ & & $<\mathrm{LOD}$ & & $<\mathrm{LOD}$ & & $<\mathrm{LOD}$ & & $<$ LOD & & $<$ LOD & & $<$ LOD & & $\angle \mathrm{LOD}$ & & $\angle$ LOD & & $<$ LOD & \\
\hline DCPU* & nd & $<\mathrm{LOQ}$ & & 6.1 & 3.5 & $\angle \mathrm{LOD}$ & & $\angle \mathrm{LOD}$ & & $<\mathrm{LOQ}$ & & $\angle \mathrm{LOD}$ & & $\angle \mathrm{LOQ}$ & & $\angle \mathrm{LOD}$ & & $<$ LOD & & $\angle \mathrm{LOQ}$ & & $<\mathrm{LOD}$ & & $\angle \mathrm{LOD}$ & \\
\hline DEA* $^{*}$ & nd & $<\mathrm{LOD}$ & & $\angle \mathrm{LOD}$ & & $<\mathrm{LOD}$ & & $\angle \mathrm{LOD}$ & & $<\mathrm{LOD}$ & & $<\mathrm{LOD}$ & & $<\mathrm{LOD}$ & & $\angle \mathrm{LOD}$ & & $<$ LOD & & $\angle \mathrm{LOD}$ & & $<\mathrm{LOD}$ & & $\angle \mathrm{LOD}$ & \\
\hline DET* & nd & $<\mathrm{LOD}$ & & $\angle \mathrm{LOD}$ & & $<\mathrm{LOQ}$ & & $\angle \mathrm{LOD}$ & & $<\mathrm{LOQ}$ & & $<\mathrm{LOQ}$ & & $<\mathrm{LOD}$ & & $\angle \mathrm{LOD}$ & & $<\mathrm{LOQ}$ & & $\angle \mathrm{LOD}$ & & $<\mathrm{LOD}$ & & $\angle \mathrm{LOQ}$ & \\
\hline DIA* & nd & $<$ LOD & & $<$ LOD & & $<\mathrm{LOQ}$ & & $<\mathrm{LOD}$ & & 286.2 & 22.8 & 182.0 & 94.2 & $<\mathrm{LOD}$ & & $<$ LOD & & $<\mathrm{LOQ}$ & & $<\mathrm{LOD}$ & & $<\mathrm{LOD}$ & & $<\mathrm{LOD}$ & \\
\hline Diuron & nd & $<\mathrm{LOQ}$ & & $\angle \mathrm{LOD}$ & & 15.0 & 0.6 & $\angle \mathrm{LOD}$ & & $<\mathrm{LOD}$ & & 14.8 & 0.9 & $\angle \mathrm{LOD}$ & & $\angle \mathrm{LOD}$ & & 15.9 & 1.1 & $\angle \mathrm{LOD}$ & & $<\mathrm{LOD}$ & & 15.5 & 0.7 \\
\hline Flazasulfuron & nd & $<$ LOD & & $<$ LOD & & $\begin{array}{l}\mathrm{LOQ} \\
\end{array}$ & & $<\mathrm{LOD}$ & & $<\mathrm{LOD}$ & & $<\mathrm{LOQ}$ & & $<\mathrm{LOD}$ & & $<$ LOD & & $<\mathrm{LOQ}$ & & $<\mathrm{LOD}$ & & $<$ LOD & & $\begin{array}{l}\mathrm{LOQ} \\
\end{array}$ & \\
\hline Isoproturon & nd & $<\mathrm{LOD}$ & & $\angle \mathrm{LOQ}$ & & 10.2 & 0.4 & $\angle \mathrm{LOD}$ & & $<\mathrm{LOQ}$ & & 10.4 & 0.5 & $<\mathrm{LOQ}$ & & $\angle \mathrm{LOD}$ & & 11.2 & 0.3 & $\angle \mathrm{LOQ}$ & & $<\mathrm{LOD}$ & & 105.0 & 0.2 \\
\hline Linuron** & nd & $<\mathrm{LOD}$ & & $\angle \mathrm{LOD}$ & & $<\mathrm{LOD}$ & & $\angle \mathrm{LOD}$ & & $<\mathrm{LOD}$ & & $<\mathrm{LOD}$ & & $<\mathrm{LOD}$ & & $\angle \mathrm{LOD}$ & & $\angle \mathrm{LOD}$ & & $\angle \mathrm{LOD}$ & & $<\mathrm{LOD}$ & & $\angle \mathrm{LOD}$ & \\
\hline Metolachlor & nd & $<\mathrm{LOD}$ & & $\angle \mathrm{LOD}$ & & $\angle \mathrm{LOD}$ & & $\angle \mathrm{LOD}$ & & $<\mathrm{LOD}$ & & $\angle \mathrm{LOD}$ & & $<\mathrm{LOD}$ & & $\angle \mathrm{LOD}$ & & $<$ LOD & & $\angle \mathrm{LOD}$ & & $<\mathrm{LOD}$ & & $\angle \mathrm{LOD}$ & \\
\hline $\begin{array}{l}\text { Oxadixyl } \\
\end{array}$ & nd & $<\mathrm{LOD}$ & & $\angle \mathrm{LOD}$ & & $<\mathrm{LOQ}$ & & $\angle \mathrm{LOD}$ & & $<\mathrm{LOD}$ & & $<\mathrm{LOQ}$ & & $<\mathrm{LOD}$ & & $\angle \mathrm{LOD}$ & & $<\mathrm{LOQ}$ & & $\angle \mathrm{LOD}$ & & $<\mathrm{LOD}$ & & $\angle \mathrm{LOQ}$ & \\
\hline Propyzamide & nd & $<\mathrm{LOD}$ & & $\angle \mathrm{LOD}$ & & $<\mathrm{LOD}$ & & $\angle \mathrm{LOD}$ & & $<\mathrm{LOD}$ & & $<\mathrm{LOD}$ & & $<\mathrm{LOD}$ & & $\angle \mathrm{LOD}$ & & $<\mathrm{LOD}$ & & $\angle \mathrm{LOD}$ & & $<\mathrm{LOD}$ & & $\angle \mathrm{LOD}$ & \\
\hline Prosulfocarb** & $\mathrm{d}$ & $<\mathrm{LOD}$ & & $\angle \mathrm{LOD}$ & & $<\mathrm{LOD}$ & & $\angle \mathrm{LOD}$ & & $<\mathrm{LOD}$ & & $<\mathrm{LOD}$ & & $<\mathrm{LOD}$ & & $\angle \mathrm{LOD}$ & & 25.4 & 4.0 & 10.6 & 0.4 & $<\mathrm{LOD}$ & & $\angle \mathrm{LOD}$ & \\
\hline Simazine** & $\mathrm{d}$ & $<\mathrm{LOQ}$ & & $<\mathrm{LOQ}$ & & $<\mathrm{LOQ}$ & & $<\mathrm{LOQ}$ & & 730.9 & 27.9 & $<\mathrm{LOQ}$ & & $<\mathrm{LOQ}$ & & 56.9 & 6.3 & 11.6 & 0.3 & 12.9 & 0.3 & 32.5 & 7.3 & $<\mathrm{LOQ}$ & \\
\hline Simazine hydroxy* & nd & $\angle \mathrm{LOD}$ & & $\angle \mathrm{LOD}$ & & $\angle \mathrm{LOD}$ & & $\angle \mathrm{LOD}$ & & $<\mathrm{LOD}$ & & $\angle \mathrm{LOD}$ & & $\angle \mathrm{LOD}$ & & $\angle \mathrm{LOD}$ & & $<$ LOD & & $\angle \mathrm{LOD}$ & & $<\mathrm{LOD}$ & & $\angle \mathrm{LOD}$ & \\
\hline Terbuthylazine** & nd & $<\mathrm{LOQ}$ & & $\angle$ LOD & & $<\mathrm{LOD}$ & & $<\mathrm{LOD}$ & & $<\mathrm{LOD}$ & & $<\mathrm{LOQ}$ & & $<\mathrm{LOD}$ & & $\angle$ LOD & & $<$ LOD & & $<\mathrm{LOQ}$ & & $<\mathrm{LOD}$ & & $\angle$ LOD & \\
\hline Terbuthylazine hydroxy* & nd & $\angle \mathrm{LOD}$ & & $\angle \mathrm{LOD}$ & & $\angle \mathrm{LOD}$ & & $\angle \mathrm{LOD}$ & & $<\mathrm{LOD}$ & & $\angle \mathrm{LOD}$ & & $\angle \mathrm{LOD}$ & & $\angle \mathrm{LOD}$ & & $<$ LOD & & $\angle \mathrm{LOD}$ & & $<\mathrm{LOD}$ & & $\angle \mathrm{LOD}$ & \\
\hline & & & & & & & & & & & ungici & & & & & & & & & & & & & & \\
\hline Azoxystrobin** & $\mathrm{d}$ & $<\mathrm{LOD}$ & & $\angle \mathrm{LOD}$ & & $<\mathrm{LOD}$ & & $\angle \mathrm{LOD}$ & & 11.6 & 1.8 & $<\mathrm{LOQ}$ & & $<\mathrm{LOD}$ & & 17.5 & 2.6 & $\begin{array}{l}\mathrm{LOD} \\
\end{array}$ & & $\angle \mathrm{LOD}$ & & $<\mathrm{LOD}$ & & $\begin{array}{ll}\mathrm{LOQ} \\
\end{array}$ & \\
\hline Carbendazim** & $\mathrm{d}$ & $<\mathrm{LOD}$ & & $\angle \mathrm{LOD}$ & & $<\mathrm{LOD}$ & & $\angle \mathrm{LOD}$ & & $<\mathrm{LOD}$ & & $<\mathrm{LOD}$ & & $<\mathrm{LOD}$ & & $<\mathrm{LOD}$ & & $<$ LOD & & $<\mathrm{LOD}$ & & $<\mathrm{LOD}$ & & $\angle \mathrm{LOD}$ & \\
\hline Dimetomorph** & nd & $<\mathrm{LOD}$ & & $<\mathrm{LOD}$ & & $<\mathrm{LOD}$ & & $<$ LOD & & $<\mathrm{LOD}$ & & $<\mathrm{LOD}$ & & $<\mathrm{LOD}$ & & $<$ LOD & & $<\mathrm{LOD}$ & & $<$ LOD & & $<\mathrm{LOD}$ & & $<\mathrm{LOD}$ & \\
\hline Epoxiconazole** & nd & $<\mathrm{LOQ}$ & & $\angle \mathrm{LOQ}$ & & $<\mathrm{LOD}$ & & 106.6 & 2.8 & 43.4 & 2.5 & $<\mathrm{LOQ}$ & & $<\mathrm{LOD}$ & & 99.5 & 5.5 & 12.6 & 0.2 & $\angle \mathrm{LOD}$ & & $<$ LOD & & $\angle \mathrm{LOD}$ & \\
\hline Metalaxyl** & nd & $<\mathrm{LOD}$ & & $<\mathrm{LOD}$ & & $<\mathrm{LOD}$ & & $<\mathrm{LOD}$ & & $<\mathrm{LOD}$ & & $<\mathrm{LOD}$ & & $<\mathrm{LOD}$ & & $\angle \mathrm{LOD}$ & & $<$ LOD & & $<\mathrm{LOD}$ & & $<$ LOD & & $<\mathrm{LOD}$ & \\
\hline Penconazole** & nd & $<\mathrm{LOD}$ & & $\angle \mathrm{LOD}$ & & $<\mathrm{LOD}$ & & $\angle \mathrm{LOD}$ & & $<\mathrm{LOD}$ & & $\angle \mathrm{LOD}$ & & $<\mathrm{LOD}$ & & $\angle \mathrm{LOD}$ & & $<$ LOD & & $\angle \mathrm{LOD}$ & & $<$ LOD & & $\angle \mathrm{LOD}$ & \\
\hline Prochloraze** & $\mathrm{d}$ & $<\mathrm{LOD}$ & & $\angle \mathrm{LOD}$ & & $<\mathrm{LOD}$ & & $\angle \mathrm{LOD}$ & & $<\mathrm{LOD}$ & & $<\mathrm{LOD}$ & & $<\mathrm{LOD}$ & & $\angle \mathrm{LOD}$ & & $\angle \mathrm{LOD}$ & & $\angle \mathrm{LOD}$ & & $\angle$ LOD & & $\angle \mathrm{LOD}$ & \\
\hline Pyrimethanil** & nd & $<\mathrm{LOD}$ & & $\angle \mathrm{LOD}$ & & $<\mathrm{LOD}$ & & $\angle \mathrm{LOD}$ & & $<\mathrm{LOD}$ & & $<\mathrm{LOD}$ & & $<\mathrm{LOD}$ & & $\angle \mathrm{LOD}$ & & $<\mathrm{LOD}$ & & $\angle \mathrm{LOD}$ & & $<\mathrm{LOD}$ & & $\angle \mathrm{LOD}$ & \\
\hline Tebuconazole** & $\mathrm{d}$ & $<\mathrm{LOQ}$ & & $<\mathrm{LOQ}$ & & $<\mathrm{LOD}$ & & $<\mathrm{LOQ}$ & & 500.3 & 21.8 & 84.9 & 42.7 & $<\mathrm{LOD}$ & & 178.4 & 67.5 & 60.4 & 3.9 & $<\mathrm{LOQ}$ & & 56.5 & 16.0 & $\angle \mathrm{LOD}$ & \\
\hline Tetraconazole & nd & $<\mathrm{LOD}$ & & $\angle \mathrm{LOD}$ & & $<\mathrm{LOD}$ & & $\angle \mathrm{LOD}$ & & $<\mathrm{LOD}$ & & $<\mathrm{LOD}$ & & $<\mathrm{LOD}$ & & $\angle \mathrm{LOD}$ & & $<\mathrm{LOD}$ & & $\angle \mathrm{LOD}$ & & $<$ LOD & & $\angle \mathrm{LOD}$ & \\
\hline & & & & & & & & & & & ssectici & & & & & & & & & & & & & & \\
\hline Imidacloprid** & $\mathrm{d}$ & $<\mathrm{LOD}$ & & $\angle \mathrm{LOD}$ & & $<\mathrm{LOD}$ & & $\angle \mathrm{LOD}$ & & $<\mathrm{LOD}$ & & $<\mathrm{LOD}$ & & $<\mathrm{LOD}$ & & $\angle \mathrm{LOD}$ & & $<$ LOD & & $\angle \mathrm{LOD}$ & & $<\mathrm{LOD}$ & & $\angle \mathrm{LOD}$ & \\
\hline Total concentrations & & $<\mathrm{LOD}$ & & 6.1 & & 40.3 & & 106.6 & & 1572.4 & & 308.5 & & $<\mathrm{LOD}$ & & 392.3 & & 161.5 & & 23.5 & & 104.0 & & 135.9 & \\
\hline
\end{tabular}


$d$ : determined in the survey; nd: not determined in the survey; < LOD: concentration below the analytical detection limit; < LOQ: concentration below the analytical quantification; *: Degradation products; **: pesticides approved in Tunisia 
Table 5 Pesticides quantified in sediments as a function of the site and the season (mean concentrations $\mathrm{ng} \mathrm{g}^{-1} \mathrm{~d}$.w; $\mathbf{n}=\mathbf{3}$ injections) and physical-chemical parameters of sediment samples

\begin{tabular}{|c|c|c|c|c|c|c|c|c|c|c|c|c|c|c|c|c|c|c|c|c|c|c|c|c|c|}
\hline \multirow{3}{*}{ Pesticides } & \multirow{3}{*}{ Survey } & \multicolumn{6}{|c|}{ Lagoon (A) } & \multicolumn{6}{|c|}{ Chegui oued (B) } & \multicolumn{6}{|c|}{ Garaa oued (C) } & \multicolumn{6}{|c|}{ Tinja oued (D) } \\
\hline & & \multicolumn{2}{|c|}{$\begin{array}{c}\text { Autumn } \\
2015\end{array}$} & \multicolumn{2}{|c|}{ Spring 2016} & \multicolumn{2}{|c|}{ Summer 2016} & \multicolumn{2}{|c|}{ Autumn 2015} & \multicolumn{2}{|c|}{ Spring 2016} & \multicolumn{2}{|c|}{ Summer 2016} & \multicolumn{2}{|c|}{ Autumn 2015} & \multicolumn{2}{|c|}{ Spring 2016} & \multicolumn{2}{|c|}{ Summer 2016} & $\begin{array}{l}\text { Autun } \\
2015\end{array}$ & & Spring 2 & 2016 & Summe & 2016 \\
\hline & & Mean & SD & Mean & SD & Mean & SD & Mean & SD & Mean & SD & Mean & SD & Mean & SD & Mean & SD & Mean & SD & Mean & SD & Mean & SD & Mean & SD \\
\hline & & & & & & & & & & & & rbicides & & & & & & & & & & & & & \\
\hline Acetochlor & nd & $<\mathrm{LOD}$ & & $<\mathrm{LOD}$ & & 4.8 & 0.7 & $<\mathrm{LOD}$ & & \begin{tabular}{|l|l|} 
LOD \\
\end{tabular} & & 2.8 & 0.3 & $<\mathrm{LOD}$ & & $\begin{array}{l}\mathrm{LOQ} \\
\end{array}$ & & $<\mathrm{LOD}$ & & $<\mathrm{LOQ}$ & & \begin{tabular}{|l|l|} 
LOD \\
\end{tabular} & & $\begin{array}{l}\mathrm{LOD} \\
\end{array}$ & \\
\hline Alachlor & nd & $<\mathrm{LOD}$ & & $<\mathrm{LOD}$ & & 2.3 & 0.9 & $<\mathrm{LOD}$ & & $\begin{array}{l}\text { LOD } \\
\end{array}$ & & 2.5 & 0.1 & $<\mathrm{LOD}$ & & $\angle \mathrm{LOD}$ & & 1.8 & 0.3 & $<\mathrm{LOQ}$ & & $<$ LOD & & $\angle \mathrm{LOD}$ & \\
\hline Atrazine & nd & $<\mathrm{LOD}$ & & $<\mathrm{LOD}$ & & $<\mathrm{LOD}$ & & $<\mathrm{LOD}$ & & $<\mathrm{LOD}$ & & $<\mathrm{LOD}$ & & $<\mathrm{LOD}$ & & $<$ LOD & & $<\mathrm{LOD}$ & & $<$ LOD & & $<$ LOD & & $<$ LOD & \\
\hline Chlortoluron & nd & $<\mathrm{LOQ}$ & & $<\mathrm{LOD}$ & & $<\mathrm{LOQ}$ & & $<\mathrm{LOQ}$ & & \begin{tabular}{|l|}
$<\mathrm{LOQ}$ \\
\end{tabular} & & $<\mathrm{LOD}$ & & $<\mathrm{LOQ}$ & & $\angle \mathrm{LOD}$ & & $<\mathrm{LOQ}$ & & $<\mathrm{LOQ}$ & & \begin{tabular}{|l|}
$<\mathrm{LOQ}$ \\
\end{tabular} & & $\angle \mathrm{LOD}$ & \\
\hline DCPMU* & nd & $<\mathrm{LOQ}$ & & $<\mathrm{LOD}$ & & $<\mathrm{LOD}$ & & $<\mathrm{LOQ}$ & & $<\mathrm{LOD}$ & & $<\mathrm{LOD}$ & & $<\mathrm{LOQ}$ & & $\angle \mathrm{LOD}$ & & $<\mathrm{LOD}$ & & $<\mathrm{LOD}$ & & $<\mathrm{LOQ}$ & & $\angle \mathrm{LOD}$ & \\
\hline DCPU* & nd & $<\mathrm{LOD}$ & & $<\mathrm{LOD}$ & & $<$ LOD & & $<\mathrm{LOQ}$ & & \begin{tabular}{|l|l|}
$<O Q$ \\
\end{tabular} & & $<\mathrm{LOD}$ & & 0.5 & 0.1 & $<\mathrm{LOD}$ & & $<\mathrm{LOD}$ & & $<\mathrm{LOQ}$ & & \begin{tabular}{|l|}
$<\mathrm{LOQ}$ \\
\end{tabular} & & $\begin{array}{l}\mathrm{LOD} \\
\end{array}$ & \\
\hline DEA* & nd & $<\mathrm{LOD}$ & & $<\mathrm{LOD}$ & & $<\mathrm{LOD}$ & & $<\mathrm{LOD}$ & & \begin{tabular}{|l|l|}
$<\mathrm{LOD}$ \\
\end{tabular} & & $<\mathrm{LOD}$ & & $<\mathrm{LOD}$ & & $<$ LOD & & $<\mathrm{LOD}$ & & $<\mathrm{LOD}$ & & \begin{tabular}{|l|}
$<\mathrm{LOD}$ \\
\end{tabular} & & $<$ LOD & \\
\hline DET* & nd & $<\mathrm{LOD}$ & & $<\mathrm{LOD}$ & & $<$ LOD & & $<\mathrm{LOD}$ & & \begin{tabular}{|l|l|}
$<\mathrm{LOD}$ \\
\end{tabular} & & $<\mathrm{LOD}$ & & $<\mathrm{LOD}$ & & \begin{tabular}{|l|l|} 
LOD \\
\end{tabular} & & $<\mathrm{LOD}$ & & $<\mathrm{LOD}$ & & \begin{tabular}{|l|}
$<\mathrm{LOD}$ \\
\end{tabular} & & $<$ LOD & \\
\hline DIA* & nd & $<\mathrm{LOD}$ & & $<\mathrm{LOD}$ & & $<$ LOD & & $<\mathrm{LOD}$ & & \begin{tabular}{|l|}
$<\mathrm{LOD}$ \\
\end{tabular} & & $<\mathrm{LOD}$ & & $<\mathrm{LOD}$ & & $<$ LOD & & $<\mathrm{LOD}$ & & $<\mathrm{LOD}$ & & $<$ LOD & & $\angle \mathrm{LOD}$ & \\
\hline Diuron & nd & $<\mathrm{LOD}$ & & $<\mathrm{LOQ}$ & & $\angle \mathrm{LOD}$ & & $<\mathrm{LOD}$ & & \begin{tabular}{|l|}
$<\mathrm{LOD}$ \\
\end{tabular} & & $<\mathrm{LOQ}$ & & $<\mathrm{LOD}$ & & $\angle \mathrm{LOD}$ & & $<\mathrm{LOD}$ & & $<\mathrm{LOQ}$ & & \begin{tabular}{|l|}
$<\mathrm{LOD}$ \\
\end{tabular} & & $\angle \mathrm{LOD}$ & \\
\hline Flazasulfuron & nd & $<\mathrm{LOD}$ & & $<\mathrm{LOD}$ & & $<\mathrm{LOQ}$ & & $<\mathrm{LOD}$ & & \begin{tabular}{|l|}
$<\mathrm{LOQ}$ \\
\end{tabular} & & $<\mathrm{LOD}$ & & $<\mathrm{LOD}$ & & $\angle \mathrm{LOQ}$ & & $<\mathrm{LOD}$ & & $<\mathrm{LOD}$ & & \begin{tabular}{|l|}
$<\mathrm{LOQ}$ \\
\end{tabular} & & $<\mathrm{LOD}$ & \\
\hline Isoproturon & nd & $<\mathrm{LOQ}$ & & $<\mathrm{LOD}$ & & $<\mathrm{LOD}$ & & $<\mathrm{LOQ}$ & & \begin{tabular}{|l|l|}
$<\mathrm{LOD}$ \\
\end{tabular} & & $\angle \mathrm{LOD}$ & & $\angle \mathrm{LOD}$ & & $\angle \mathrm{LOD}$ & & $<\mathrm{LOQ}$ & & $<\mathrm{LOD}$ & & \begin{tabular}{|l|l|}
$<\mathrm{LOD}$ \\
\end{tabular} & & $<\mathrm{LOQ}$ & \\
\hline Linuron*** & nd & $<\mathrm{LOD}$ & & $<\mathrm{LOQ}$ & & $<$ LOD & & $<\mathrm{LOD}$ & & \begin{tabular}{|l|}
$<\mathrm{LOQ}$ \\
\end{tabular} & & $<\mathrm{LOD}$ & & $<\mathrm{LOD}$ & & $<$ LOD & & $<\mathrm{LOQ}$ & & $<\mathrm{LOD}$ & & \begin{tabular}{|l|}
$<\mathrm{LOD}$ \\
\end{tabular} & & $\angle \mathrm{LOQ}$ & \\
\hline Metolachlor & nd & $<\mathrm{LOD}$ & & $<\mathrm{LOD}$ & & 1.5 & 0.1 & $<\mathrm{LOD}$ & & \begin{tabular}{|l|}
$<\mathrm{LOD}$ \\
\end{tabular} & & 0.8 & 0.2 & $<\mathrm{LOD}$ & & $<$ LOD & & 0.7 & 0.1 & $<\mathrm{LOD}$ & & \begin{tabular}{|l|}
$<\mathrm{LOQ}$ \\
\end{tabular} & & $\angle$ LOQ & \\
\hline Oxadixyl & nd & $<\mathrm{LOD}$ & & $<\mathrm{LOD}$ & & $<$ LOD & & $<\mathrm{LOQ}$ & & $<\mathrm{LOD}$ & & $<\mathrm{LOD}$ & & $<\mathrm{LOQ}$ & & $<\mathrm{LOD}$ & & $<\mathrm{LOD}$ & & $<\mathrm{LOD}$ & & $<\mathrm{LOD}$ & & $\angle \mathrm{LOQ}$ & \\
\hline Propyzamide & nd & $<\mathrm{LOD}$ & & $<\mathrm{LOD}$ & & $<$ LOD & & $<\mathrm{LOD}$ & & \begin{tabular}{|l|}
$<\mathrm{LOD}$ \\
\end{tabular} & & $<\mathrm{LOQ}$ & & $<\mathrm{LOQ}$ & & $\angle \mathrm{LOD}$ & & $<\mathrm{LOD}$ & & $<\mathrm{LOD}$ & & $<\mathrm{LOQ}$ & & $\angle \mathrm{LOD}$ & \\
\hline Prosulfocarb** & $\mathrm{d}$ & $<\mathrm{LOD}$ & & $<\mathrm{LOD}$ & & $<$ LOD & & $<\mathrm{LOD}$ & & \begin{tabular}{|l|}
$<\mathrm{LOD}$ \\
\end{tabular} & & 5.0 & 0.1 & 6.3 & 0.3 & 4.1 & 0.6 & 5.2 & 0.3 & $<\mathrm{LOD}$ & & \begin{tabular}{|l|}
$<\mathrm{LOD}$ \\
\end{tabular} & & $\angle \mathrm{LOQ}$ & \\
\hline Simazine** & $\mathrm{d}$ & $<\mathrm{LOD}$ & & $<\mathrm{LOD}$ & & $<\mathrm{LOD}$ & & $<\mathrm{LOQ}$ & & $<$ LOD & & $<\mathrm{LOD}$ & & $<\mathrm{LOQ}$ & & $\angle \mathrm{LOD}$ & & $<\mathrm{LOQ}$ & & $<\mathrm{LOD}$ & & $<$ LOD & & $\angle \mathrm{LOD}$ & \\
\hline $\begin{array}{l}\text { Simazine } \\
\text { hydroxy* }\end{array}$ & nd & $<\mathrm{LOD}$ & & $<\mathrm{LOD}$ & & $<$ LOD & & $<\mathrm{LOD}$ & & $<\mathrm{LOQ}$ & & $<\mathrm{LOD}$ & & $<\mathrm{LOD}$ & & $<\mathrm{LOD}$ & & $<$ LOD & & $<\mathrm{LOD}$ & & $<\mathrm{LOD}$ & & $<$ LOD & \\
\hline Terbuthylazine** & nd & $<\mathrm{LOD}$ & & $<\mathrm{LOD}$ & & $<$ LOD & & $<\mathrm{LOQ}$ & & \begin{tabular}{|l|}
$<\mathrm{LOD}$ \\
\end{tabular} & & $<\mathrm{LOD}$ & & $<\mathrm{LOD}$ & & $\angle \mathrm{LOQ}$ & & $<\mathrm{LOD}$ & & $<\mathrm{LOD}$ & & $<\mathrm{LOQ}$ & & $\angle \mathrm{LOD}$ & \\
\hline $\begin{array}{l}\text { Terbuthylazine } \\
\text { hydroxy* }\end{array}$ & nd & $<\mathrm{LOD}$ & & $<\mathrm{LOD}$ & & $<$ LOD & & $<\mathrm{LOD}$ & & $<\mathrm{LOD}$ & & $<\mathrm{LOD}$ & & $<\mathrm{LOD}$ & & $<\mathrm{LOD}$ & & $<$ LOD & & $<\mathrm{LOD}$ & & $<\mathrm{LOD}$ & & $<$ LOD & \\
\hline & & & & & & & & & & & & ngicides & & & & & & & & & & & & & \\
\hline Azoxystrobine*** & $\mathrm{d}$ & $<\mathrm{LOD}$ & & $<\mathrm{LOD}$ & & $\begin{array}{l}\mathrm{LOD} \\
\end{array}$ & & \begin{tabular}{|l|l|} 
LOD \\
\end{tabular} & & \begin{tabular}{|l|} 
LOD \\
\end{tabular} & & $<\mathrm{LOD}$ & & $<\mathrm{LOD}$ & & $\begin{array}{l}\mathrm{LOD} \\
\end{array}$ & & $<\mathrm{LOD}$ & & $<\mathrm{LOD}$ & & $<\mathrm{LOD}$ & & $\begin{array}{l}\mathrm{LOD} \\
\end{array}$ & \\
\hline Carbendazim** & $\mathrm{d}$ & $<\mathrm{LOD}$ & & $<\mathrm{LOD}$ & & $<$ LOD & & $<\mathrm{LOD}$ & & $\begin{array}{l}\text { LOD } \\
\end{array}$ & & $<\mathrm{LOD}$ & & $<\mathrm{LOD}$ & & $\angle \mathrm{LOD}$ & & $<\mathrm{LOD}$ & & $<\mathrm{LOD}$ & & \begin{tabular}{|l|}
$<\mathrm{LOD}$ \\
\end{tabular} & & $\begin{array}{l}\mathrm{LOD} \\
\end{array}$ & \\
\hline Dimetomorph** & nd & $<\mathrm{LOQ}$ & & $<\mathrm{LOQ}$ & & $<\mathrm{LOQ}$ & & $<\mathrm{LOD}$ & & $<\mathrm{LOD}$ & & 0.7 & 0.1 & $<\mathrm{LOQ}$ & & $<$ LOQ & & $<\mathrm{LOD}$ & & $<\mathrm{LOD}$ & & \begin{tabular}{|l|l|} 
\\
\end{tabular} & & $<$ LOD & \\
\hline Epoxiconazole** & nd & $<\mathrm{LOD}$ & & $<\mathrm{LOD}$ & & $<\mathrm{LOD}$ & & 1.0 & 0.1 & \begin{tabular}{|l|l|}
$<O Q$ \\
\end{tabular} & & 0.8 & 0.2 & 4.2 & 0.5 & 3.3 & 1.7 & $<\mathrm{LOD}$ & & $<\mathrm{LOD}$ & & \begin{tabular}{|l|l|}
$<\mathrm{LOD}$ \\
\end{tabular} & & $<\mathrm{LOD}$ & \\
\hline Metalaxyl** & nd & $<\mathrm{LOD}$ & & $<\mathrm{LOD}$ & & $<\mathrm{LOD}$ & & $<\mathrm{LOD}$ & & \begin{tabular}{|l|l|}
$<O Q$ \\
\end{tabular} & & $<\mathrm{LOD}$ & & $<\mathrm{LOD}$ & & $\angle \mathrm{LOQ}$ & & $<\mathrm{LOD}$ & & $<\mathrm{LOD}$ & & $<$ LOD & & $\angle \mathrm{LOQ}$ & \\
\hline Penconazole** & nd & $<\mathrm{LOD}$ & & $<\mathrm{LOD}$ & & $<\mathrm{LOD}$ & & \begin{tabular}{|l|}
$<\mathrm{LOD}$ \\
\end{tabular} & & \begin{tabular}{|l|l|}
$<\mathrm{LOD}$ \\
\end{tabular} & & $<\mathrm{LOD}$ & & $<\mathrm{LOD}$ & & $\angle \mathrm{LOD}$ & & $<\mathrm{LOD}$ & & $<\mathrm{LOD}$ & & \begin{tabular}{|l|}
$<\mathrm{LOD}$ \\
\end{tabular} & & $\angle \mathrm{LOD}$ & \\
\hline Prochloraze** & $\mathrm{d}$ & $<\mathrm{LOD}$ & & $<\mathrm{LOD}$ & & 1.2 & 0.7 & $<\mathrm{LOD}$ & & \begin{tabular}{|l|l|}
$<O D$ \\
\end{tabular} & & 1.8 & 0.1 & $<\mathrm{LOD}$ & & $<\mathrm{LOD}$ & & 1.2 & 0.5 & $<\mathrm{LOD}$ & & \begin{tabular}{|l|}
$<\mathrm{LOD}$ \\
\end{tabular} & & $\angle \mathrm{LOQ}$ & \\
\hline Pyrimethanil** & nd & $<\mathrm{LOD}$ & & $<\mathrm{LOD}$ & & $<\mathrm{LOD}$ & & $<$ LOD & & \begin{tabular}{|l|l|}
$<\mathrm{LOD}$ \\
\end{tabular} & & $<\mathrm{LOD}$ & & $\angle \mathrm{LOD}$ & & $<\mathrm{LOD}$ & & $<\mathrm{LOD}$ & & $<$ LOD & & \begin{tabular}{|l|}
$<\mathrm{LOD}$ \\
\end{tabular} & & $<\mathrm{LOD}$ & \\
\hline Tebuconazole** & $\mathrm{d}$ & $<\mathrm{LOD}$ & & $<\mathrm{LOD}$ & & $<$ LOD & & 1.4 & 0.1 & 31.1 & 2.3 & 5.1 & 1.1 & 8.9 & 0.3 & 6.2 & 1.1 & 5.7 & 0.8 & $<\mathrm{LOD}$ & & \begin{tabular}{|l|}
$<\mathrm{LOD}$ \\
\end{tabular} & & $<\mathrm{LOQ}$ & \\
\hline Tetraconazole & nd & $<\mathrm{LOD}$ & & $<\mathrm{LOD}$ & & $<\mathrm{LOD}$ & & $<\mathrm{LOD}$ & & $<$ LOD & & $<\mathrm{LOD}$ & & $<\mathrm{LOD}$ & & $<\mathrm{LOD}$ & & $<\mathrm{LOD}$ & & $<\mathrm{LOD}$ & & \begin{tabular}{|l|}
$<\mathrm{LOD}$ \\
\end{tabular} & & $\angle \mathrm{LOD}$ & \\
\hline & & & & & & & & & & & & ecticides & & & & & & & & & & & & & \\
\hline Imidacloprid** & $\mathrm{d}$ & $<\mathrm{LOD}$ & & $<\mathrm{LOD}$ & & $<\mathrm{LOD}$ & & $<\mathrm{LOD}$ & & \begin{tabular}{|l|l|} 
LOD \\
\end{tabular} & & $<\mathrm{LOD}$ & & $<\mathrm{LOD}$ & & $<\mathrm{LOD}$ & & $<\mathrm{LOD}$ & & $<\mathrm{LOD}$ & & $<\mathrm{LOD}$ & & $<\mathrm{LOD}$ & \\
\hline $\begin{array}{c}\text { Total } \\
\text { concentration }\end{array}$ & & $<\mathrm{LOD}$ & & $<\mathrm{LOD}$ & & 9.8 & & 2.4 & & 31.1 & & 19.5 & & 19.9 & & 13.6 & & 14.6 & & $<\mathrm{LOD}$ & & $<\mathrm{LOD}$ & & $<\mathrm{LOD}$ & \\
\hline & & & & & & & & & & Phys & sico-ch & nical para & imeter & & & & & & & & & & & & \\
\hline$\%<63 \mu \mathrm{m}$ & & $\overline{69}$ & & $\overline{66}$ & & $\overline{12}$ & & $\overline{63}$ & & 77 & & 62 & & 100 & & $\overline{94}$ & & 100 & & 57 & & 11 & & $\overline{1}$ & \\
\hline TOC (\%) & & 1 & & 1 & & 1 & & 1 & & 1 & & 1 & & 2 & & 2 & & 2 & & 1 & & 2 & & 1 & \\
\hline
\end{tabular}


$d$ : determined in the survey; $n d:$ not determined in the survey; < LOD: concentration below the analytical detection limit; < LOQ: concentration below the analytical quantification; *: Degradation products; **: pesticides approved in Tunisia; TOC (\%) : percentage of total organic carbon; \% $\% 3$ um : percentage of finer grain size fractions. 
Click here to access/download Supplementary Material Supplementary material.doc 